\title{
Historical and Language Contacts and a Place-Name on Samos and in Macedonia (Greece): Karlóvasi
}

\section{DEMETRIUS J. GEORGACAS}

In honor of Professor Andreas Tietze, the distinguished Turcologist, University of California at Los Angeles and Universität Wien, for his sixtieth birthday.

\section{CONTENTS}

Introductory, 1-2

Bibliography, 2-5; acknowledgements, 6 ; phonetic symbols, 6

I. Karlovasi in Samos, 6-21

historical background, 7-11

description of K., 11-12

the name forms, 12-13

review of etymological attempts, $14-21$
1. Slavic, 15-17
2. Greek, 17-20
3. Turkish, 20-21

II. Karlovast in Macedonia, 21-23

historical background and description, 21-22

the story of the names, 22

attempts at explanation, 22-23

III. The interpretation of the names, 23-29

the Turkish name, 24

members of compound, 24-25

element $-s l, 25-26$

realia, 26

Turkish parallels, 26-29

Professor Tietze's suggestion, 29-30.

Addendum, 30

IV. Index, 31-33

\section{INTRODUCTORY}

Place-name study is grounded in linguistics but requires, in addition, historical, geographic, and topographic information on the area and considerable combinations, adequate knowledge of synchronic and/or successive contacts of peoples who lived in the same area and of their respective languages in interaction and interference. The results are, consequently, commensurate with the spectrum of these requirements. The study of 
place-names and other names contributes to the linguistic picture but also, and primarily, to the illumination of the past history of the area concerned. Since few scholars are usually so profoundly equipped, it is methodology that guides such place-name research and leads it to satisfactory results. The motto in the end is: there is no substitute for patient and painstaking search for the truth, i.e. what really happened in the past.

When I commenced work on this little topic in 1966, I did not anticipate the various angles of the matter that subsequently came up. First of all, I was unaware of how adversely the renaming of places turns out to affect onomastics and, more specifically, place-name study; in this respect, the name Karlovasi is a case in point. When a researcher decides to investigate everything that constitutes the history of a name, for a long time he may believe that this name is a single occurrence, but, as he patiently advances in his quest, it is found that a second occurrence of the same name is buried under a new name that replaced the old half a century earlier.

Next comes the usual question of the origin of the place-name. The Turkish possibility had been readily condemned by several writers in favor of any other etymology and even a Slavic explanation was espoused in preference to the Turkish. In a step by step effort, the true origin was established to be valid for both occurrences, one in Samos, the territory of our starting-point, and the other in central Macedonia, this latter being an area populated solely by Turks prior to 1923 .

Third, the important aspect of realia sometimes proved to have a direct relation with the naming process but not necessarily in other instances; e. g., the elevation in the valley of northwest Samos amounts to ca. $40 \mathrm{~m}$. but in the case of the valley in the Kilkis area it reaches $128 \mathrm{~m}$.; in the first case snow is rare, in the second it is abundant, and yet the name seems to have been given on account of the same element in both cases.

\section{BIBLIOGRAPHY}

\section{Abbreviations of Some Titles}

Arch. Hist. Lex. see 2. Bibliography.

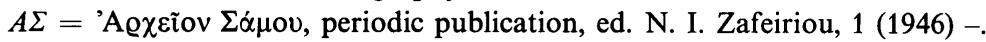

Athens T. D. = Telephone Directory of Athens. 1964 and 1972.

$B S A=$ British School (at Athens) Annual, 1 (1894) -.

$B S L=$ Bulletin de la Société de linguistique de Paris.

$C M H=$ Cambridge Mediaeval History. 1966.

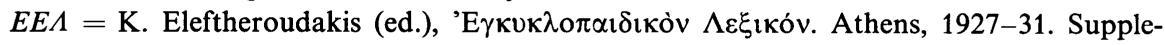
ment, 1-3 [no date; ca. 1965-70].

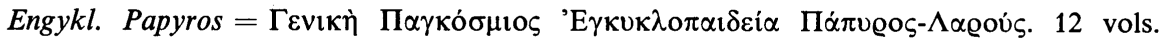
Athens, 1963.

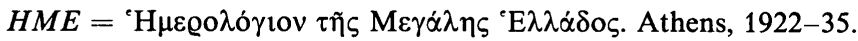

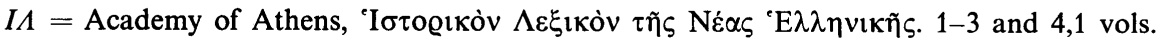
1933-53. 


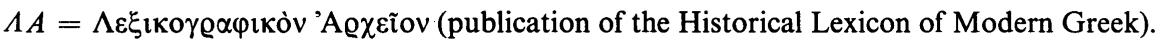
Athens, vol. 6 (1923).

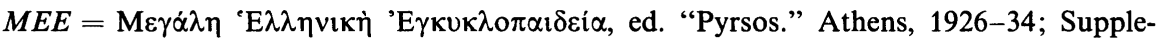
ment, 1-4 (1958-68) [no date].

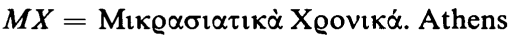

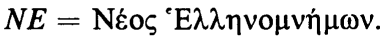

$R E=$ Pauly-Wissowa-Kroll, Realencyklopädie der klassischen Altertumswissenschaft, 2. Reihe.

Stoicheia $=\Sigma \tau$ o $\chi \varepsilon \tilde{\alpha} \alpha$.(see 2. Bibliography).

\section{Bibliography}

Article 'E $E \lambda \alpha \dot{\alpha} \varsigma, E E \Lambda 5$ (1929), a map of communications in Greece, inserted between pp. 460 and 461.

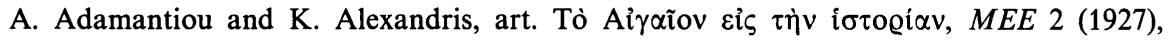
429-438 [Byzantine period, 433-6; Turkokratia and Modern period, 436-8].

A. Alexopoulos, art. K $\alpha \varrho \lambda o ́ \beta \alpha \sigma l, E E \Lambda$, Supplement, $2.620 \mathrm{~b}$.

Anonymus, art. $\Sigma \dot{\alpha} \mu \mathrm{o}$, Engykl. Papyros 11 (1963), 745-7.

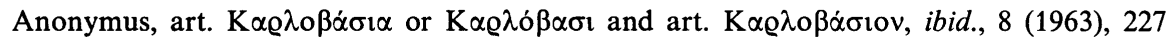
[unimportant].

Anonymus, art. K $\alpha \varrho \lambda o ́ \beta \alpha \sigma \mathrm{l}, E E \Lambda 7$ (1929), 306a.

Arch. Hist. Lex. = Archives of the Historical Lexicon of Modern Greek and its Dialects. Center of the Academy of Athens [information drawn by the author in the summer of 1966].

Athens T. D. = Athens Telephone Directory. Athens, 1964 and 1972.

L. Bürchner, art. Samos 4, RE, 2. Reihe, 1 (1920), 2162-2218 [Bibliography (up to 1909), $2165 \mathrm{f}$; map of Samos and surroundings by Bürchner, $2169 \mathrm{f}$.; on Karlovasi 2175; etc.

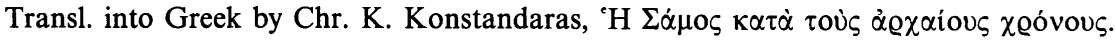
Athens, 1955].

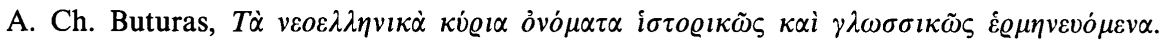
Athens, 1912.

R. M. Dawkins, Modern Greek in Asia Minor. Cambridge (England), 1916.

J[ean] Deny, art. Les noms composés en turc de Turquie, BSL 50 (1954), 144-161 [brought to my attention by Prof. A. Tietze].

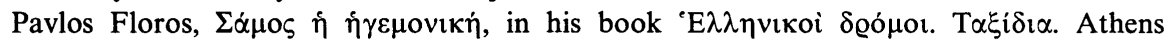

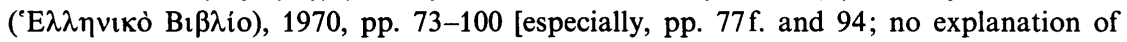
the name Karlovasi is offered].

D. J. Georgacas, Family Names of the Combined Municipality of Triple Karlovasi, culled by - - from the registers of the same municipality. List compiled on July 30, 1966. [The list consists of 355 family names, distributed among the three constituent towns as follows: Paleó Karlóvasi 155, Meséo K. 117, Néo K. 83. Some of those registered came from other villages of Samos and some are very recent additions (refugees and others) from other parts of Greece. In the registers the recurrent names amount to thousands.] Joseph Georgirenes (Archbishop of Samos), A Description of the Present State of Samos, Nicaria, Patmos, and Mount Athos. London: W. G.; sold by Moses Pitt, 1678. Photocopy edition by Bookstore of Notis Karavias. Athens, 1967. 112 pages. [Written in

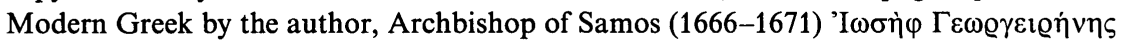
of the island of Melos, and translated by another person. Pp. 1-53: A description of the isle of Samos and of its present state at this day; that is, a survey of its condition under the Turkish rule, how it is governed, what revenues it yields, with a geographical description of the country. P. $20 \mathrm{f}$.: a few details on Carlovasy as the second largest town of the island about the last quarter of the seventeenth cent.]

F. W. Hasluck, art. Depopulation in the Aegean Islands and the Turkish Conquest, BSA 17 
(1910-11), 151-81 [on Samos, pp. 169-71; conclusions, 172-75]. Cf. also his art. Albanian Settlements in the Aegean Islands, ibid. 15 (1908-9), 223-28 [on Samos, 226-28].

H. \& R. Kahane, Italienische Ortsnamen in Griechenland. Athen, 1940. (Texte und Forschungen zur Byz.-neugriech. Philologie, ed. N. A. Bees, Nr. 36.) [On the historical background of the area, p. 9; names of persons and places on p. 272.]

H. \& R. Kahane and Andreas Tietze, The Lingua Franca in the Levant. Urbana, Ill., 1958. [On the contacts of Venetians and Turks with the Greeks in Greece and in the Aegean, 3-9.]

E. Kirsten und W. Kraiker, Griechenlandkunde: ein Führer zu klassischen Stätten ${ }^{4}$. Heidelberg (Winter), 1962 [on Samos, pp. 540-54, 816f.; bibliography, p. 845].

Chr. K. Konstandaras (transl.), L. Bürchner, Samos im Altertum. Athens, 1955. 150 pages [a preface by the translator, pp. 3-29].

[T. C. Içişleri Bakanliği, İller İdaresi Genel Müdürlügü] Köylerimiz (Our Villages). Ankara, Başbakanlık Basmevi D.S.I., 1968. 790 pp. [Beside the general register, pp. 7-590, a separate register lists the old Turkish village names alphabetically along with the new ones, pp. 595-790. However, these massive renamings do not refer to the period between the Register of 1946-1950 and 1968 but must be most recent, since some places listed in the Register of 1945-50 are not found in the list of the old names of 1968, pp. 595-790.]

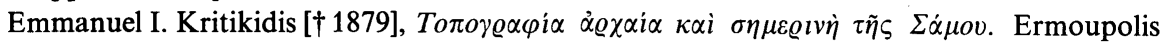
(of the island of Syros), 1869. [The author was a native of Karlovasia. On p. 84 on

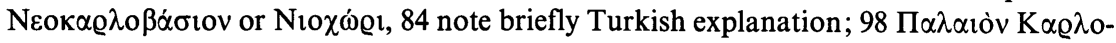

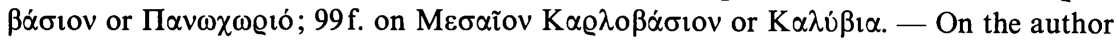
Kritikidis see N. I. Zafeiriou, $A \Sigma 3(1948-54)$, 241f.]

S. E. Lykoudis, $\Phi \alpha \varrho o \delta \varepsilon i \kappa \tau \eta \zeta \tau \tilde{\omega} v \dot{\varepsilon} \lambda \lambda \eta v \imath \kappa \tilde{\omega} v \dot{\alpha} \kappa \tau \tilde{\omega} v^{2}$. Athens, 1957.

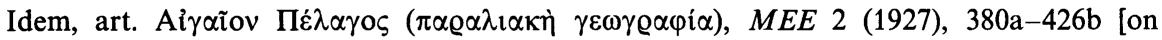
pp. $414 \mathrm{f}$. data on the island of Samos, capes, gulfs, ports, bays, anchorages, islets].

Idem and others, art. $\Sigma \dot{\alpha} \mu o \zeta, M E E 21$ (1933), 490a-513c. [S. E. Lykoudis, geography, 490a; G. K. Georgalas, geology, 490a-b; I. D. Vakirdzis, physical geography, 490b-491a (S. E. Lykoudis, cartography, 491a); I. D. Vakirdzis, economic geography, 491a-492c; idem, political geography, 492c-495c; idem, history, 495b-500b; B. D. Theophaneidis, archeology, 500b-511c; I. D. Vakirdzis, folklore, 511c-512b; idem, church history, 512b-513a; G. P. Anagnostopoulos, language, 513a-b.]

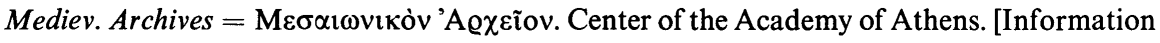
drawn by the author in the summer of 1966.]

Mediterranean Pilot. Vol. IV, comprising the islands of the Greek Archipelago ${ }^{8}$. British Navy: Hydrographic Department. London, 1955 -.

Sultana J. Michaliadou, Samos. Athènes, 1953. 113 pages. [Pp. 57-74: Poésies et Musique; 67-74: Notes complémentaires; 79-115: Pythagore (Pythagoras) (extraits) traduit du grec. Unimportant.]

S. P. Pavlis $(\Pi \propto \nu \lambda \eta \tilde{\eta})$ ), A list of 64 toponyms in the area of the triple-town municipality of Karlovasi, put together on Georgacas' request. Karlovasi, August 1966.

A. Philippson, Die griechischen Landschaften. Eine Landeskunde, herausg. von E. Kirsten. Vol. 4: Das Aegaeische Meer und seine Inseln. Frankfurt a. M., 1959.

Idem, Reisen und Forschungen im westlichen Kleinasien. 5 vols. Gotha, 1910-15. (Ergänzungshefte zu Petermanns Mitteilungen, Nr. 167, 172, 177, 180, 183.)

Piri reis [Captain Piri], Kitabı bahriye (Portulan of the Mediterranean). A short version, 1521 (published in part by Paul Kahle). The detailed version, 1526, published in a facsimile reproduction, Istanbul, 1935. (Türk Tarihi Araştırma Kurumu yayınlarından, 2.) [It describes the island of Samos (pp. 185-187), mostly the ports, going clockwise around the island. P. 185 on Karlovasi; a river on the map (p. 187) carries the name Karkılık Çayı going east along the north shore, i.e. "river of the reeded area" (karkl "very large 


\section{A Place-Name on Samos and in Macedonia (Greece): Karlóvasi}

reeds" grow there). This item (along with its relevant content) and the following item were brought to my attention by the courtesy of Prof. Tietze.]

Idem, Haritası [Map]. Istanbul, 1935. (Türk Tarihi Araştırma Kurumu yayınlarından, 1.)

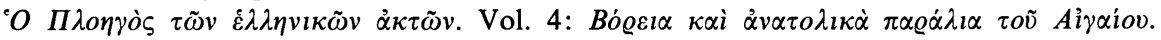
2nd ed. Athens, 1955. (Edition of the Hydrographic Office of the Greek Navy.) [191f. on the harbor and the three settlements constituting the municipality of Karlovasi, information on related matters.] Of the new third ed. in 4 vols. only the first vol. ( $\Delta v \tau$ ik $\alpha i$ $\dot{\alpha} \kappa \tau \alpha i)$ has appeared, in 1971.

L. Robert et Jeanne Robert, La Carie. 2 vols. Paris, 1954.

L. Robert, Noms indigènes. Paris, 1963.

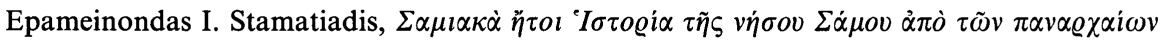

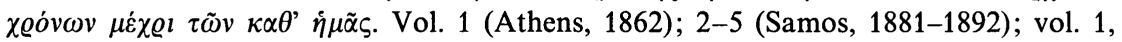
2nd ed. [Cf. N. I. Zafeiriou (biography of Stamatiadis), $A \Sigma 3$ (1948-54), 238f.]

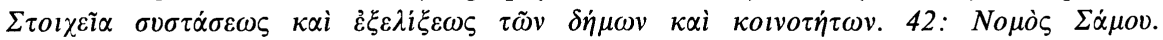

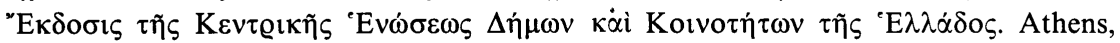

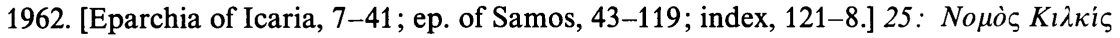
[Eparchia of Kilkis, 8-133; community of Stathmos, 114f.; index, 193-207. The name $\mathrm{K} \alpha \varrho \lambda \dot{o} \beta \alpha \sigma \mathrm{l}$ appears in parentheses only in the index (p. 198), not in the text (p. 114f.), where $\mathrm{K} \varrho \eta \tau \iota \kappa \dot{\alpha}$ and 'A $A \varepsilon \xi \xi_{\alpha}^{\alpha} v \delta \varrho \alpha$ are listed as two of the constituent settlements and since

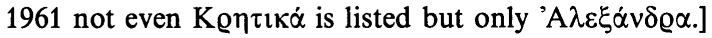

(Rev.) H. F. Tozer, The Islands of the Aegean. Oxford, 1890. [This sort of travelogue gives general impressions and indicates the objects of greatest interest; chapter VIII. Samos, pp. 157-177. Not very important.]

Türkiye'de Meskûn Yerler Kllavuzu (Register of Inhabited Places in Turkey). Parts I and II, pp. 1-558, 561-1234. Ankara, 1946 and 1950.

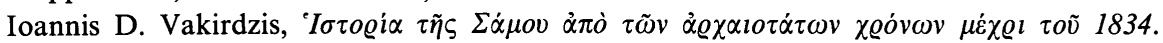
Samos, 1912. 8-vo. $360 \mathrm{pp}$.

Idem, art. $\Sigma \dot{\alpha} \mu \mathrm{o}, E E \Lambda 11$ (1931), pp. 310b-313 [with a map of the nomos of Samos, p. 312].

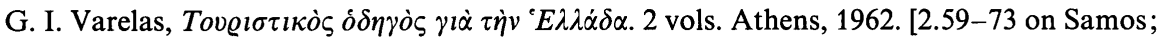
on p. 71 a map; on p. 64 on Karlovasi.]

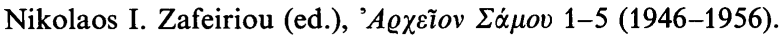

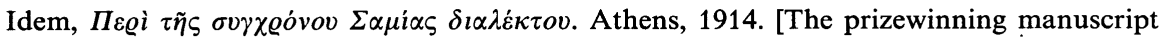

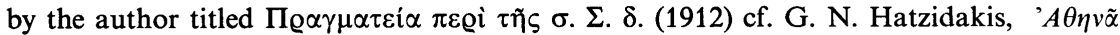
25 (1913), 300-304.] The new edition of this work appeared in installments: $\Sigma \alpha \mu i \alpha \delta \dot{\alpha} \alpha-$ $\lambda \varepsilon \kappa \tau 0 \zeta, A \Sigma 2$ (1947), 204-211; 237-240; 3 (1948-54), 165-198; 4 (1955), 185-206;

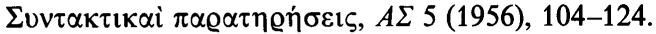

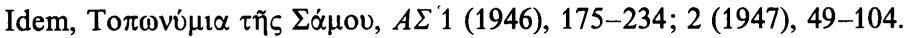

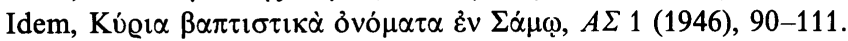

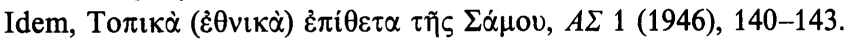

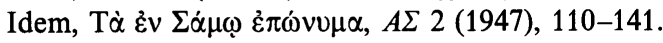

Idem, K $\alpha \varrho \lambda \hat{\beta} \beta \alpha \sigma \mathrm{l}, A \Sigma 1$ (1946), 219-221.

Idem, art. K $\alpha \varrho \lambda o ́ \beta \alpha \sigma \mathrm{l}, M E E 13$ (1930), 853c-854a; Supplement, 3.275a.

Information firsthand

On July 30, 1966 I stayed for a day in Karlovasi to gather useful information and look through the registers of the municipality of the three towns: Néo Karlóvasi, Paleó Karlóvasi, and Meséo Karlóvasi. Mr. Stamatis Pavlis (see above in Bibliography), then secretary of the municipality (who had once migrated to the United States), put at my disposal the registers of the period 1954-1966 and also the municipal rolls of each Karlovasi and gave me additional information about the provenance of families. The mayoralty was set up in $\mathbf{1 9 5 2}$ and the first mayor, Mr. Theodoros Talambekas, was installed on April 8, 1953; mayor in 1966 was Mr. Emmanuel N. Inglesis, shipowner. In July 1972 I visited briefly Paleó Karlóvasi to view its terrain. 


\title{
Acknowledgments
}

I am obliged to several friends of Samos, other friends and colleagues. My thanks go to Prof. Andreas Tietze of the University of California for his always courteous, generous, and prompt advice (per letters from Vienna dated 2. II., 22. III., 4. IV. 1972, and 6. XI. 1973, and from Los Angeles 22. XI. 1972), to Mr. Stamatis P. Pavlis (Karlovasi) for his help, to Mr. Fotis Komborozos (Athens) for preparing for me copies of Stamatiadis' relevant material (Jan. 1969). Mr. Kostas Ptinis, editor and publisher of the local newspaper 'E $2 \lambda \alpha \dot{\alpha} \varsigma$ (Samos), offered me requested information orally and by correspondence (letters of 14 and 29. IX. 1965 and 20.III, and 4 and 15.IV.1972). Mr. Panayotis Kourouvanis (Ayios Kirykos, Icaria) was able repeatedly to get some relevant information from a gymnasium instructor in Ayios Kirykos who hails from Karlovasi. Dr. Demetrios Polemis (Piraeus and Apatouria, Andros) supplied me (1971) with information from two books inaccessible to me. Professor Demetrios Loukatos and Miss Anthoula Goulousi, both of Athens, provided some requested printed matter; the latter sent me also photocopies and notes made from other material (Feb. 1972).

For information on Kritika, the former Karlovasi, in the area of Kilkis I am indebted to several persons in Macedonia. Mr. Evangelos G. Kafandaridis, elementary school teacher (Mikrovrysi, Kilkis), son of a Greek from Trapezounda and of a mother from Kars in Caucasus, supplied me with substantial information on the background of Karlovasi and vicinity in Kilkis (per letters of 12 and 30.I and 18.II.1972). Professor Demetrios Petropoulos was instrumental in getting information about the subject from Mr. Basil Mekras, agriculturist, and Nikolaos Arvanitidis, native of Kritika (formerly Karlovasi) of Kilkis; Messrs I. Kolokas and Ant. Drilias both helped in bringing Mr. Petropoulos into contact with the informants.

To all the above colleagues and friends I am deeply indebted for their kind and varied assistance. At the last moment my thanks go to my long-time friends and colleagues, Prof. Edmund Berry of the University of Manitoba and Prof. Conrad Rothrauff, the Editor of Names, for reading the typescript and offering me their comments and stylistic suggestions.

\section{Phonetic Symbols}

I note here a few phonetic symbols, most being Turkish, used in the text: $\hat{a}$ and $\hat{u}$ long vowels in Turkish
$c|d z|$
$\mathcal{f}$, (capital) $C \zeta / t \check{s} \mid$
$\breve{g} / \gamma$ fricative/
$i$, (capital) $\dot{I} / \mathrm{i} /$
$l$, (capital) $I$
$\ddot{o}$ (as in German)
$\ddot{u}$ (as in German)

\author{
$s|\check{s}|$ \\ $\check{s}$ /as Engl. sh/ \\ lj $|\hat{l}|, n j|\bar{n}|$ \\ $\check{e}$ (Slavic transcription), $b, b$ \\ é, è (in French) of transcribed words \\ $\dot{a}, \dot{e}, \dot{i}, \dot{o}, \dot{u}$ are in accented syllables \\ * (asterisk) for reconstructed forms
}

\section{KARLOVASI IN SAMOS}

The survey of the geographical, historical, and topographical data of the SE Aegean and, of course, especially those of the area of Samos in connection with adjacent SW Anatolia is the starting-point for any placename investigation. 


\section{HISTORICAL BACKGROUND}

The island of Samos is geologically found to represent just a promontory of Asia Minor with whose Mycale mountain range it once was solidly connected by land; the island is separated from the Anatolian coast (where Caria was) by a narrow strait $(2,375 \mathrm{~m}$. across and $54 \mathrm{~m}$. deep).

With regard to our topic, while we may dispense with the ancient history of the island, its closer medieval history is obscure. In the Byzantine Empire it constituted, along with the entire southern coast of Asia Minor, one administrative unit, one thema; during the last part of the Byzantine period the island was ruined by invasions, earthquakes, and epidemics. The invasions and occupation came from the west, the Venetians and the Genoese, and these were followed by the Turks. More specifically, from 1204 on, the Venetians captured Lesbos (1204), Chios (1124), and the Frankish got Icaria (1207); the Genoese took Smyrna (1261; jointly ruled with the Johannites, 1344-1401), seized Icaria (1304-29; 1346-1481; Johannites, 1481-1523), Lesbos (1333; Genoese Catelusi, 1355-1462), and Chios (1346). Samos belonged to the Venetians (1207-1304) and to the Genoese (1304-1329; 1346-1475; Genoese Giustianiani of Chios, 1413-1475). All these places fell to the Turks: Smyrna 1417, the islands in the fifteenth and sixteenth centuries: Samos 1501, Icaria 1522, Chios 1566. 1

Piracy was the major plague of the islands during the Middle Ages. The Furni like the Spalmadori (Oinoussai) and Moskonisi groups (Moschonisia) were a haunt of the pirates who preyed on the traffic, i.e. the coasters between Egypt and South Asia Minor and Constantinople. The islands of Samos and Psara, being possessions of the Giustiniani of Chios, were much vexed by corsairs and were simply at their mercy. The result was that the populations of both islands were removed and deported by the Giustiniani to Chios, and both islands were deserted for a hundred years. The Samians consented to their en masse removal by the Genoese and settled in Chios (and in part in Lesbos and in Patmos) in a year sometime between 1463 and 1472, so that Samos was virtually deserted (only a few families were left behind).

Samos was resettled about one century later, owing to the initiative of the Turkish admiral Kılıc Ali Paşa (who died 1587); the resettlement, which naturally was gradual and lasted several years (between ca. 1560

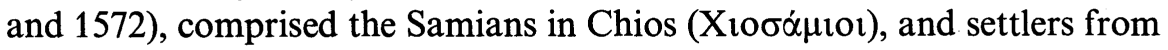

1 Cf. Kirsten and Kraiker, Griechenlandkunde 4 (1962), p. 540, 544 (bibliography, 845); Kahane, Italienische Ortsnamen in Griechenland (1940), 9; Kahane and Tietze, The

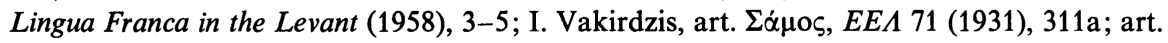

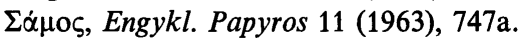


Asia Minor, the Aegean Islands, including Lesbos, also Icaria (K $\alpha \varrho \mathrm{t} \omega-$ $\tau \alpha i$ i $\alpha$ in Karlovasi), Naxos ('A $\xi \omega \tau o \lambda o ́ \gamma 1$ also in Karlovasi), the Peloponnesus (e.g. Gytheion and Vatika), Sterea Ellas, and Euboea (town Kov $\mu \alpha i$ i $\alpha$ in Samos). ${ }^{2}$ The first capital of the island was for some time in the last quarter of the sixteenth century Kilıc-köy (later renamed Múloı) in honor of the Turkish admiral who was responsible for the resettlement

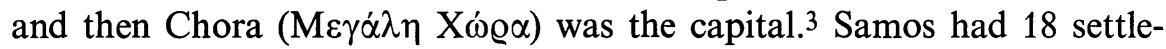
ments in 1677.4 The pattern of the resettlement is reflected in the names of the settlements and of the settlers themselves, a matter that was not considered at all by Hasluck.

The name of the island still is the prehellenic one, $\Sigma \dot{\alpha} \mu{ }_{0}$, meaning probably "elevation," not replaced through history. In Modern Greek while the official and common form is $\eta \sum \dot{\alpha} \mu \varsigma_{\varsigma} / i$ Sámos/, the regional and demotic form has been $\dot{\eta} \Sigma \dot{\alpha} \mu \mathrm{o}$ as are other island names $\dot{\eta} \mathrm{M} \tilde{\eta} \lambda \mathrm{o}, \dot{\eta} \mathrm{N} \alpha \dot{\xi} \mathrm{o}_{\mathrm{o}}$, $\dot{\eta}$ Nió, $\dot{\eta} \Pi \alpha \dot{\alpha} \varrho$, $\dot{\eta}$ Xío, etc. The Turkish (official) name for "Samos" is Sisam-adası (official name) and the more popular variant Susam-adast "Samos-island," recorded since the beginning of the sixteenth century, is obviously a transformation of the Greek expression st Sámu in the local dialec-

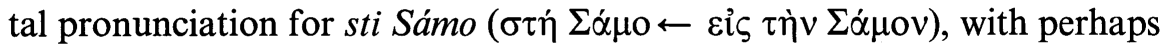
folketymological influence of Turkish susam "sesame," which is also Greek

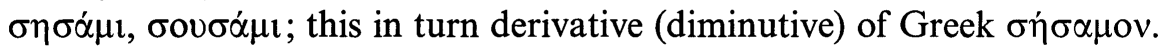
Cf. parallel Turkish folk transformations, e.g. Samsún from s Amisón ( $\varepsilon i \varsigma$ 'A $\mu \iota \sigma o ́ v)$, and for the second element cf. the Turkish name for another Greek island in the vicinity: Altın-adast "Golden island" for Lesbos. The patrial (inhabitant) name of the islander was and in learned usage still is $\Sigma \dot{\alpha} \mu 10 \varsigma$ (fem. $\Sigma \alpha \mu i \alpha$ ) but common Modern Greek $\Sigma \alpha \mu \iota \dot{\tau} \tau \eta_{\varsigma}$ (fem.

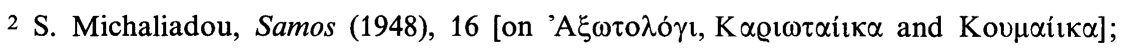
on Kou $\mu \alpha i$ i $\alpha$ as a municipality since 1918: Stoicheia $42.74 \mathrm{f}$.

3 On the resettlement of Samos Georgirenes, A Description (1678), p. 2 and passim; Stamatiadis, $\Sigma \alpha \mu l \alpha \kappa \dot{\alpha} 2$ (1881), 7f.; Hasluck, BSA 15 (1908-9), 226-8; 17 (1910-11), 169f.; N. I. Zafeiriou, $A \Sigma 4$ (1955), 5-11. - Hasluck insists that the colonization in 1572 "was Albanian or partly Albanian settlement" (BSA 15.223), as if the Albanians were in the majority (Albanian was still spoken on the island in the seventeenth cent.), and conjectures that these Albanians were prisoners taken by Uluc-Ali in his Adriatic expedition before Lepanto (1571) or in the suppression of a nearly contemporary rebellion fomented by Venice in the Drin or Boiana country (BSA 17.174); in the same stretch he stamps a statement that the inhabitants of the villages Arvanitochori and Leka in Samos had come from the Pelo-

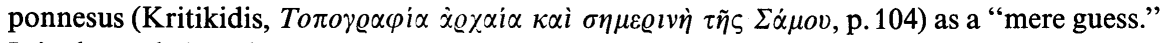
It is shown below that Kritikidis is right and Hasluck was guessing.

4 Georgirenes, A Description (1678), p. 4. 
$\Sigma \alpha \mu \iota \dot{\tau} \tau(\sigma \sigma \alpha) .{ }^{5}$ On the point of the settlement of the Samos countryside we should explore the various parts thereof.

\section{Moraïtes.}

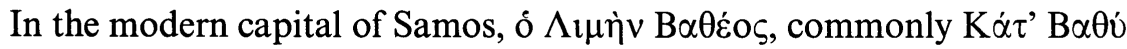
(renamed $\Sigma \dot{\alpha} \mu \mathrm{o} \zeta$ in 1961), the first inhabitants came from the Peloponnesus (Mo@iás) and settled in a district of Vathy which was invisible from the

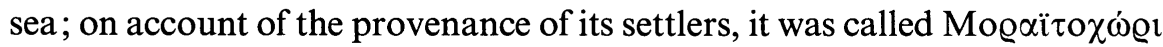

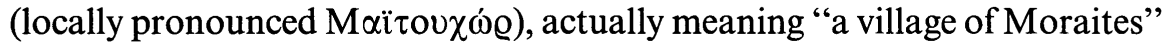

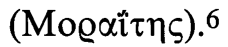

The name for "Peloponnesians" is reflected, furthermore, in other parts

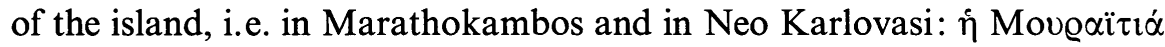
(= Mog $\alpha i \tau^{\tau} \alpha$ ) is the designation of the district at the $\mathrm{N}$ edge of Marathokambos, given naturally as a consequence of the fact that Peloponnesians

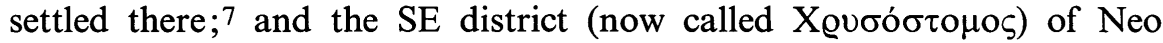

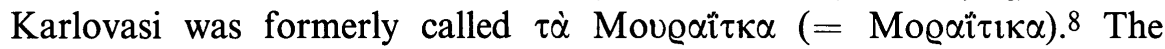
above amply shows that Greek people from the Peloponnesus had settled places in Samos.

\section{Mytileneans.}

The settlement (north of Chora) that became a village and a community

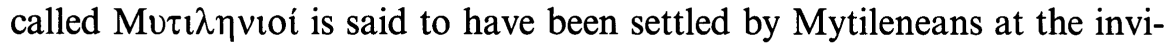
tation of K1lic Ali, as Georgirenes tells us, ${ }^{9}$ and its name being originally

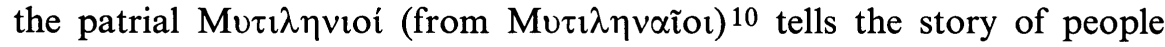

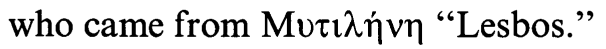

5 Ancient $N \alpha \varrho \theta \eta \kappa i \zeta$ is since the Middle Ages $\Sigma \alpha \mu$ to $\pi$ ov́ $\lambda \alpha$ (spelled Samio Paulo by the translator of Georgirenes' Description, p. 15). The islet still written $\Sigma \alpha \mu$ เо $\pi$ oú $\lambda \alpha$ (with 58 inhabitants in 1920 and four in 1961) is part of the community oi $\Sigma \pi \alpha \theta \alpha \varrho \alpha i$ ol. The actual name, however, has been sambúla and derives from samubúla (this from $\Sigma \alpha \mu \mathrm{o} \pi$ ov́ $\lambda \alpha$ "little

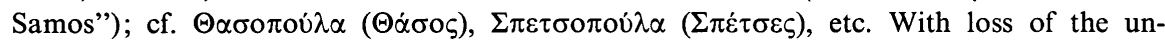
accented $u$ (from $o$ ) and assimilation in voicing of the consonant $p$, i.e. $m p \rightarrow m b$, we receive sambúla. The official name $\Sigma \alpha \mu$ io

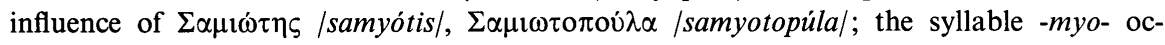
curring in the latter names was transferred also to $\Sigma \alpha \mu o \pi$ oú $\lambda \alpha$ and replaced the syllable -mo-, the latter becoming $\Sigma \alpha \mu$ เо $\pi$ oú $\lambda \alpha$.

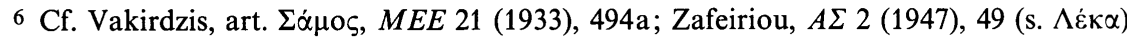
and 55.

7 Zafeiriou, $A \Sigma 2$ (1947), 62.

8 Ibid., 103.

9 Georgirenes, A Description (1678), p. 25.

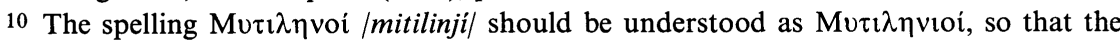

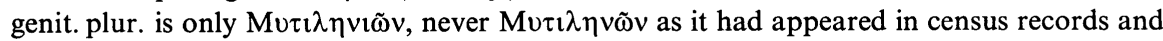

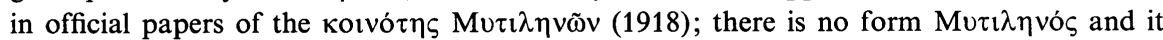

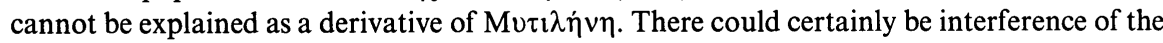

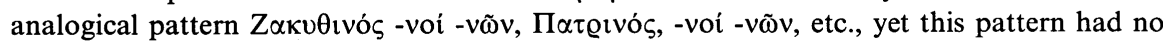

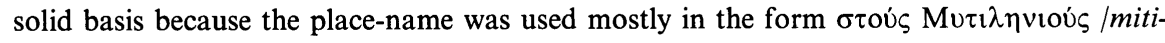
linjus/ and this form withstood the analogical impact. 


\section{Vourliotes.}

The name oi Bov@ $\lambda \iota \tilde{\omega} \tau \varepsilon \varsigma$, designating a cape and a large village on the peak of a mountain, relates the provenance of these settlers from $\tau \dot{\alpha}$ Bov@ $\lambda \dot{\alpha} /$ vurlá/ (Turkish Urla) in Ionia, a city in the center of the Erythraia Peninsula, west of Smyrna and close to Klazomenai.11

\section{Arvanites.}

The Albanian-speaking settlers in Samos seem to have come here from Greek Arvanitochoria because, for one thing, Kilic Ali wished settlers from Greek parts to participate in this colonization; secondly, the indications become forceful through the settlement results. There is no denying that Albanian settlers came to Samos for the evidence is anthroponyms

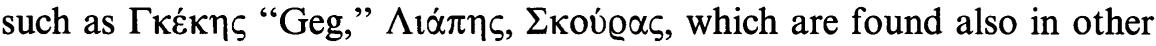
parts of Greece.

A settlement was called ' $A \varrho \beta \alpha v i \tau \varepsilon \varsigma$ and then it developed into two ham-

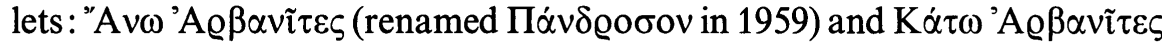

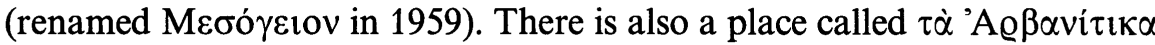
$\mathrm{K} \alpha \lambda \dot{u} \beta \imath \alpha$, ruins of a settlement outside Chora on the road between the latter and Pyrgos;12 the first part of the expression is a derivative of

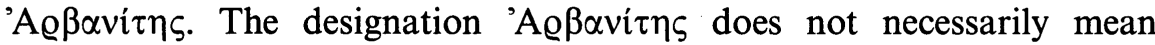
"Albanian of Albania" but usually signifies the "Greek-Albanian" or "Albanian-speaking Greek citizen."

The hamlet $\tau$ ov $\Lambda \dot{\varepsilon} \kappa \alpha$ (officially $\dot{\eta} \Lambda \dot{\varepsilon} \kappa \alpha$ ) in the NW region of Samos ${ }^{13}$

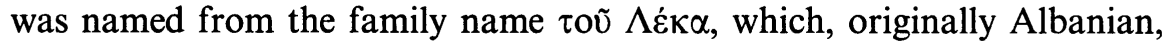
occurs in parts of continental Greece.

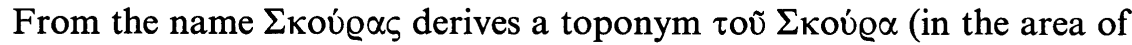
Furni) and (from the plural) the toponym oi $\Sigma \kappa o v \ln \delta \varepsilon \varsigma$ (in the area of

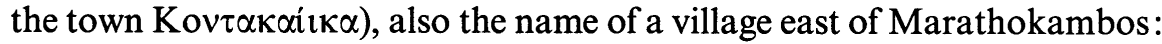

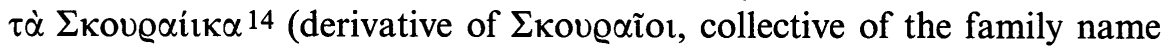

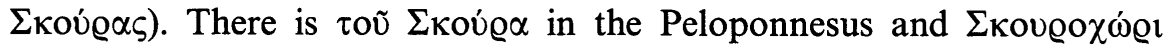
in Elis. ${ }^{15}$

11 Georgirenes, A Description, p. 22; cf. E. I. Stamatiadis, $\Sigma \alpha \mu \imath \alpha \kappa \dot{\alpha} 2$ (1881) 34; N. E.

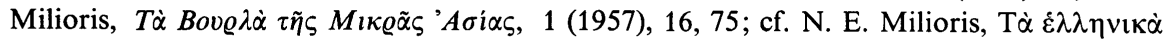

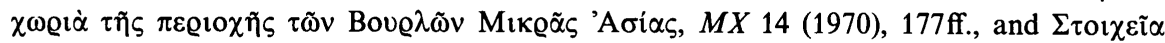

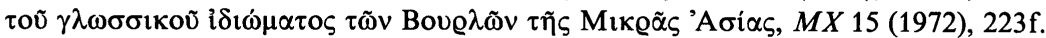

12 Zafeiriou, $A \Sigma 2$ (1947) 49; K. Themelis, $A \Sigma 2.251$.

13 Georgirenes, A Description (1678), 20 (cf. also Vakirdzis, 'I $\sigma \tau o \varrho i \alpha ~ \tau \tilde{\eta} \varsigma \Sigma \dot{\alpha} \mu o v$ [1912] 111f.); Zafeiriou, $A \Sigma 2.49$.

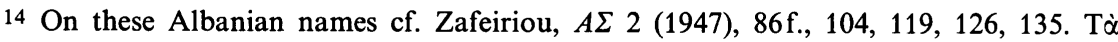
$\Sigma \kappa o v \varrho \alpha i$ i $\alpha$ has been a community since 1918 ; Stoicheia 42.106 .

15 It is from Skourochori in Elis that the well-known Skouras Brothers in California had come. 
An Albanian toponym is $\Psi \alpha \varrho \imath$ in Samos below the village Kastanéa; this is an Albanian name in Triphylia, Corinthia, Gortynia, and elsewhere. 16

\section{Other Settlers.}

Samian surnames, at least in part, show the provenance of other settlers in addition to the aforementioned.

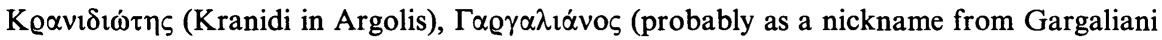

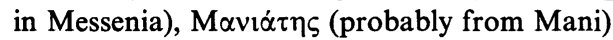

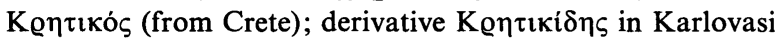

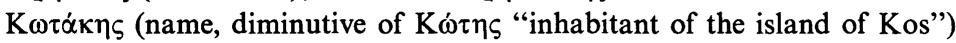

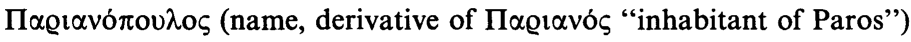

$\Pi \alpha \xi$ ivó $\varsigma$ (probably from Paxi)

$\Sigma \kappa о \pi \varepsilon \lambda i \tau\rceil$ (from Skopelos)

Poditns (from Rhodes)

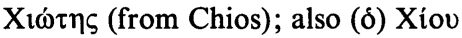

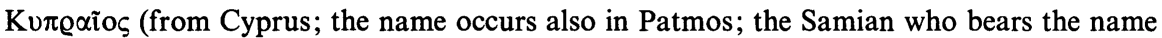

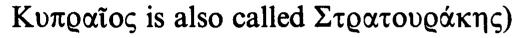

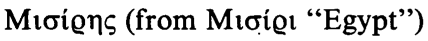

There are more such names, as one may see in Zafeiriou's list, arranged according to patrial suffixes and amounting to ten percent of the Samian surnames. ${ }^{17}$

It is certainly true that some of these names may represent single individuals who settled in the island without families; to establish the precise data would be a task in itself and would be a worthwhile project for a local historiographer.

\section{DESCRIPTION OF KARLOVASI}

While the ancient major city on the island, called Samos, was situated where Tigáni (actually "Frying-pan" from the shape of the enclosed port) is now located, during the Turkish period till the late nineteenth cent. the capital was Chora, not far from the ruins of ancient Samos, while in modern

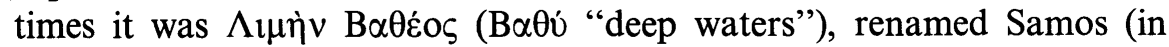
1958). The second largest town on the island is $K \alpha \varrho \lambda$ ó $\beta \alpha \sigma \mathrm{t}$. It was in the

16 See D. J. Georgacas and W. A. McDonald, Placenames of Southwest Peloponnesus (Athens, 1967; published 1969), 284 (No. 8635) and 340 (No. 9257).

$17 A \Sigma 2.110-141$; patrial suffixes, 113; statistics 111 . 


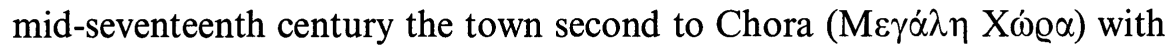
500 houses and five churches, and producing muscat wine and onions. 18

The first settlers and inhabitants of Karlovasi were Peloponnesians, Icarians, Naxians, Cretans, Euboeans, and other islanders. ${ }^{19}$ The $\Pi \alpha \lambda \alpha$ iò

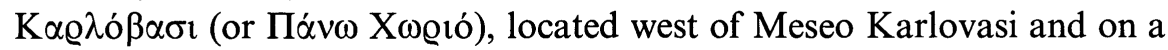
mountain, is the oldest of the three and was built on the spot called $\Pi \alpha \lambda i \dot{\alpha}$ $\beta \varrho v i \sigma \eta$ by Peloponnesians from Nafplio and by Icarians; 20 the names of

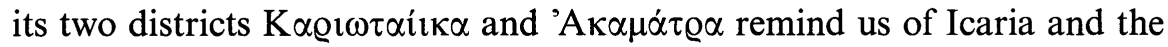
Icarian village called Akamatra. ${ }^{21}$ North and above Old Karlovasi are the ruins of an ancient castle, commonly called K $\alpha \sigma \tau$ @í.

There are now three towns under one municipal administration: Néo Karlóvasi (or Niochóri) or simply Karlóvasi, founded on the spot called

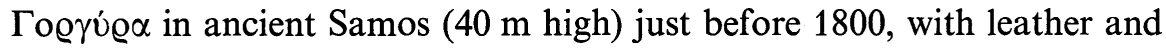

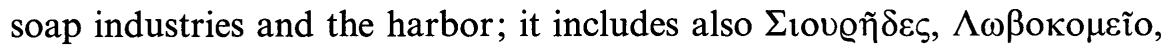
and the Movì

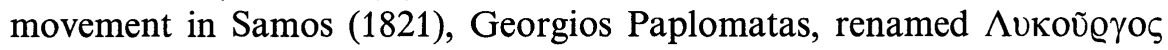

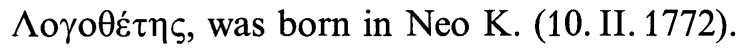

Meséo Karlóvasi or Mésa Chorió (or till ca. 1900 Kalývia "huts"), west of Neo K., and $40 \mathrm{~m}$ high.

Paleó Karlóvasi (or Páno Chorió); it was originally called simply Karlóvasi (200 $\mathrm{m}$ high).22

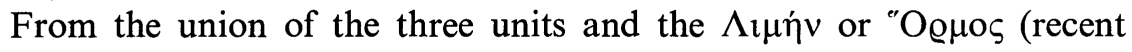
name) emerged the municipality of Karlovásia ( $\delta \tilde{\eta} \mu \circ \varsigma \mathrm{K} \alpha \varrho \lambda \circ \beta \alpha \sigma i \omega v)$ in 1952.23

\section{THE NAME FORMS}

The name $\tau$ ò $K \alpha \varrho \lambda$ ó $\beta \alpha \sigma$ l was originally attached to one delimited area only and the other places, now constituents of Greater Karlovasi, bore dif-

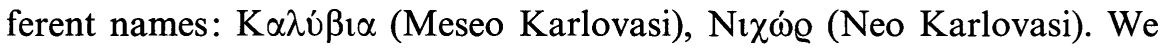

18 On the description of Karlovasi by Joseph Georgirenes, A Description (1678), p. $20 \mathrm{f}$.

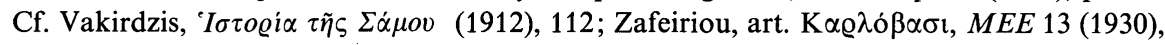
$854 \mathrm{a}$.

On the harbor of Karlovasi a succinct description was given in the Mediterranean Pilot, vol. IV (1955), 408 (with plan of the harbor); Lykoudis, $\Phi \alpha \varrho o \delta \varepsilon i \kappa \tau \eta \varsigma \tau \tilde{\omega} v \varepsilon \lambda \lambda \eta v ı \kappa \tilde{\omega} v$ $\dot{\alpha} \kappa \tau \tilde{\omega} v^{2}$ (1957), 300 .

The harbor was built (from 1871 on) on the site called $\Sigma \chi 0$ õvo ; Stamatiadis, $\Sigma \alpha \mu l \alpha \kappa \dot{\alpha} 4$ (1886), 25.

19 Stamatiadis, $\Sigma \alpha \mu \imath \alpha \kappa \dot{\alpha} 4.22$.

20 Ibid., 4.24.

21 Ibid., loc. cit.

22 Cf. Zafeiriou, art. K $\alpha Q \lambda o ́ \beta \alpha \sigma \mathrm{l}, M E E 13$ (1930), 853c-854a; idem, $A \Sigma 1$ (1946), 219f.;

Stamatiadis, $\Sigma \alpha \mu l \alpha \kappa \alpha \dot{~ 4.4,22-25 . ~}$

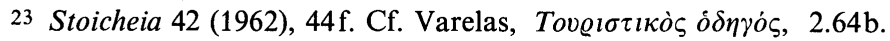


also can state that the name Karlovasi, though representing a port, however has not been found recorded in the Greek portolanos of the sixteenth century; this may mean that the name emerged during Turkokratia since the Turks took the island (1501) or it was resettled in the second half of the sixteenth century.

The chief name is to karlóvasi: $\mathrm{K} \alpha \mathrm{Q} \lambda \hat{\beta} \beta \alpha \sigma \mathrm{l}$ (without dialectal changes); tu karlóvas ${ }^{24}$ is the local dialectal form, as it was pronounced by the

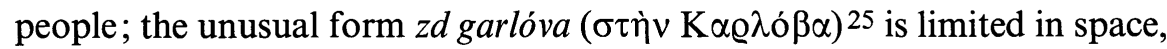
actually to the western part of Samos;

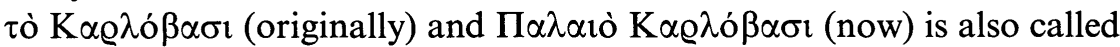

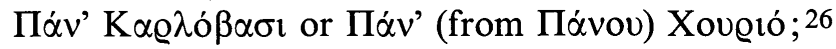

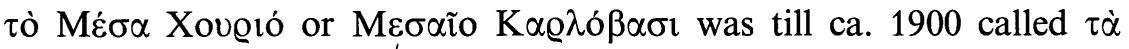
$\mathrm{K} \alpha \lambda \dot{\beta} \beta \iota \alpha$

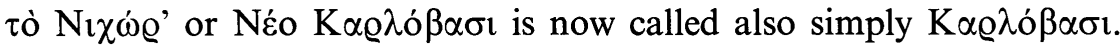

The official collective form $\tau \dot{\alpha} \mathrm{K} \alpha \varrho \lambda \mathrm{o} \beta \dot{\alpha} \sigma 1 \alpha$ is old and has the genitive plural form $\tau \tilde{\omega} \nu \mathrm{K} \alpha \varrho \lambda \mathrm{\rho} \beta \alpha \sigma i \omega v .{ }^{27}$ This is reflected in today's bureaucratese: $\delta \tilde{\eta} \mu \circ \varsigma \mathrm{K} \alpha \varrho \lambda \circ \beta \alpha \sigma i \omega v$ (since 1952), whose official constituents are four:

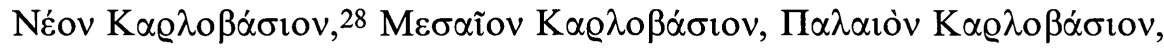
and $\Lambda \iota \eta \dot{\nu} v \mathrm{~K} \alpha \varrho \lambda \circ \beta \alpha \sigma i \omega v .{ }^{29}$

The plural form $\tau \dot{\alpha} \mathrm{K} \alpha \varrho \lambda \mathrm{o} \beta \dot{\alpha} \sigma \alpha /$ karlovása/ is the local pronunciation and resulted from the form karlovásja with the loss of the semivowel $|j|$.

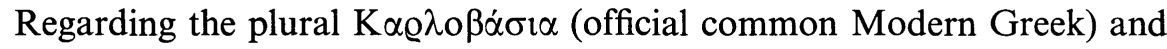
$\mathrm{K} \alpha \varrho \lambda \circ \beta \dot{\alpha} \sigma \alpha$ (Samian dialectal) one may require an explanation but it presents no problem: homonymous place units are expressed in the plural form of the shared name or even in the plural form of the prevalent name of

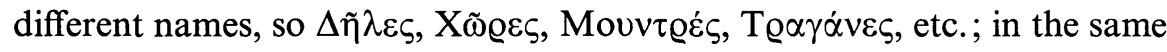
way, the pluralization Karlovásja was the natural outcome of the side-byside existence in speech of the three village units bearing the name Karlóvasi.

24 Cf. Zafeiriou, $A \Sigma 1$ (1946), 220; 5 (1956), 114.

25 The form is discussed and explained below, p. $16 \mathrm{f}$.

26 Cf. Zafeiriou, $A \Sigma 1.219 \mathrm{f}$.

27 Stamatiadis, $\sum \alpha \mu l \alpha \kappa \dot{\alpha}, 4.25$ ( $\left.\tau \dot{\alpha} \mathrm{K} \alpha \varrho \lambda \circ \beta \dot{\alpha} \sigma l \alpha\right)$; 1.7, 13, 21, 23, 24, 28, 30, 31 and 4.3,

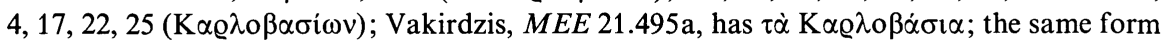
$\tau \dot{\alpha} \mathrm{K} \alpha \varrho \lambda_{\circ} \beta \dot{\alpha} \sigma 1 \alpha$ is found on two maps (EEA 5 [1929] after page 460, and 11 [1931], 312).

28 Stoicheia 42 (1962), 44. Kritikidis gives also the compounded name form N8o-

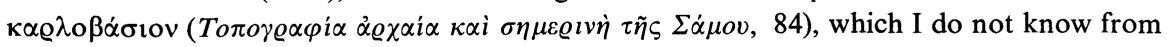
any other source; it may be his own creation.

29 Ibid., $44 \mathrm{f}$. 


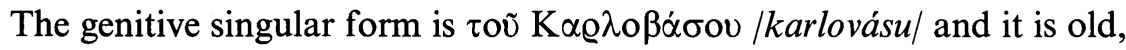
at least 150 years, ${ }^{30}$ and still used today. ${ }^{31}$ This form seems to me to be a made-up learned form created analogically on the basis of the just aforementioned plural $\tau \dot{\alpha} \mathrm{K} \alpha \varrho \lambda \circ \beta \dot{\alpha} \sigma \alpha$. The nominative-accusative form $\tau$ ò $\mathrm{K} \alpha \varrho \lambda \hat{o} \beta \alpha \sigma o v^{32}$ is a fictitious puristic hapax legomenon, though it is under-

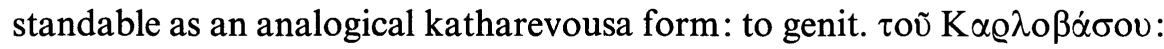
nomin.-accus. $\tau$ ò $K \alpha \varrho \lambda$ ó $\beta \alpha \sigma o v .{ }^{33}$

The patrial of $K \alpha \varrho \lambda o ́ \beta \alpha \sigma l$ has commonly been $K \alpha \varrho \lambda o \beta \alpha \sigma i \tau \eta \zeta$ since at least as early as 1834,34 in actual local pronunciation karluvasit's and plural karluvasitis, 35 with fem. K $\alpha \varrho \lambda \circ \beta \alpha \sigma i \tau \imath \sigma \sigma \alpha$, and $\mathrm{K} \alpha \varrho \lambda \circ \beta \alpha \sigma i \omega \tau \eta \varsigma$,

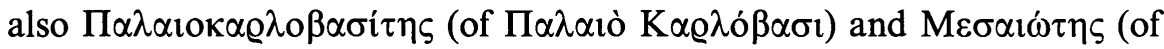

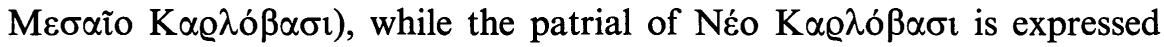

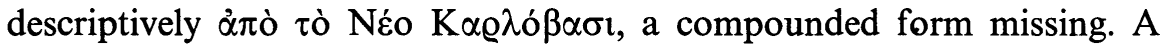
puristic patrial $\mathrm{K} \alpha \mathrm{Q} \lambda \mathrm{o} \beta \alpha \alpha_{\sigma} \mathrm{Ko} \zeta^{36}$ is hardly to be heard on the island.

\section{REVIEW OF ETYMOLOGICAL ATTEMPTS}

Etymological efforts of laymen were as copious in the past as they are in our time; they are usually based on little or no knowledge of change in language, of contacts between people speaking different languages, of behavior in name giving, and most of all on no method; their results were, therefore, commensurate with any or all of these weaknesses. Today, however, when onomastics is a science and it is actually called onomastic sciences, we should learn more about language in general and of languages in a given area and learn method in name research before we expect to

30 It figures in a text of an application of 1834: $\dot{\eta} \dot{\varepsilon} \pi \imath$

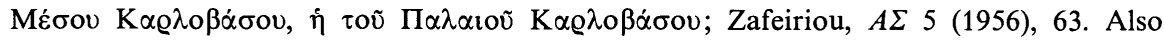

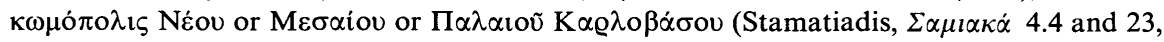

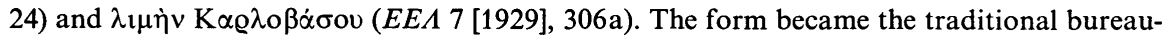

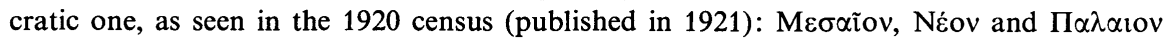

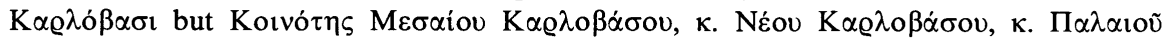

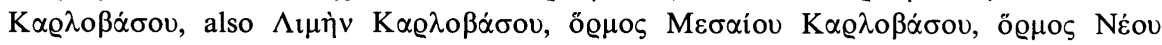

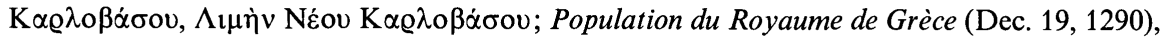
Athens, 1921, p. 272.

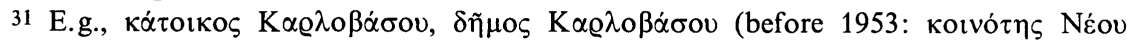

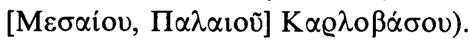

32 The katharevousa pattern for the analogy is solid; cf. $\beta \lambda \varepsilon \varphi \dot{\alpha} \varrho \circ v-\beta \lambda \dot{\varepsilon} \varphi \alpha \varrho o v, \kappa \alpha \varrho \delta \dot{\alpha}-$

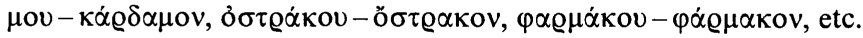

33 The form tò $\mathrm{K} \alpha \varrho \lambda \hat{\alpha} \beta \alpha \sigma o v$ is given as a second one: s. article $\mathrm{K} \alpha \varrho \lambda \hat{o} \beta \alpha \sigma \mathrm{l}, E E \Lambda$ 7.306a.

34 In the same document mentioned above (note 30), p. 65 .

$35 \mathrm{~K}$. Ptinis per letter dated 20. III. 1972.

36 Noted also by Mr. Ptinis, ibid. 
reach meaningful and satisfactory results in place-name study. In this respect, the case of Karlóvasi seems to me to be instructive. I present in the following the suggestions advanced by various individuals with criticisms of the details, reserving my own conclusions for the chapter The Interpretation.

\section{SLAVIC}

\section{Karlovo}

The place-name Karlovo in East Bulgaria near Plovdiv (Philippoupolis), of recent origin according to local sagas, was explained from Turkish qarli-ova "snow-covered plain." 37 However, Karlovo proved to be Slavic in derivation and was connected with a man's name Carlo, in Turkish Qarli. The mosque in Karlovo was erected in 1485 by 'Ali, son of Qarli, a descendant of Carlo (Arabic ibn Qarli "descendant of Q."); also Mehemmed Beg, a Qarli-zâde and a landowner in the vicinity of Skoplje, erected a mosque in Skoplje a decade later, in 1495.38

\section{Karlovasi}

In the case of Karlóvasi the refuge to a Slavic source was made despite the fact that Slavs had hardly settled on the island of Samos during the Middle Ages, as was the case, in fact, with mainland Greece and some other islands. The author who advanced this etymology, N. I. Zafeiriou, did not really consider the name of Slavic origin, however, but only its

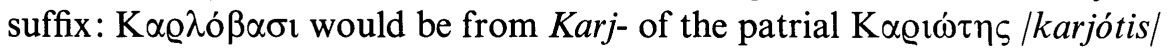
"inhabitant of Icaria," 39 and Karj- would have changed into Karl-, and the Slavic suffix -ova attached. 40 To corroborate his theory, the author states that the first settlers of old Karlovasi were Icarians from the village Akamatra in north Icaria (as the section of old Karlovasi called Akamátra shows) 41 and that the Peloponnesians, who settled Neo Karlovasi, were the namegivers and named old Karlovasi Karjóva $(\mathrm{K} \alpha \varrho \gamma i o ́ \beta \alpha)$.

37 C. J. Jireček, Das Fürstentum Bulgarien (Wien, Leipzig und Prag, 1891), p. 435.

38 F. Babinger, "Beiträge zur Geschichte von Karli-eli, vornehmlich aus osmanischen

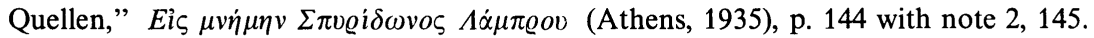

39 I may add here the surname K $\alpha \varrho 1 \omega \tau o \gamma \lambda$ ov in Neo Karlovasi, that is a patronymic with

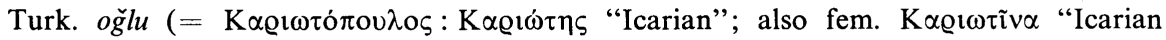

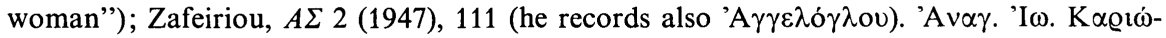

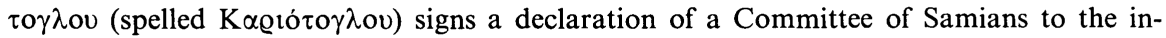
habitants of Samos along with six other signatories (document dated May 28, 1834), in

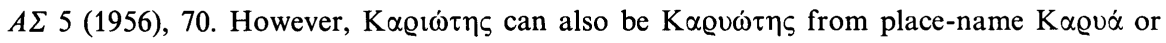

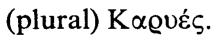

40 N. Zafeiriou, $A \sum 1$ (1946), $220 \mathrm{f}$.

41 See above, p. 16. - A quarter in Neo Karlovasi was called K $\alpha \varrho \iota \tau \tau \alpha$ iı $\alpha$. 
Zafeiriou asserts that the form $\eta \mathrm{K} \alpha \varrho \lambda$ ó $\beta \alpha$ is the earliest form of $\mathrm{K} \alpha Q$ $\lambda$ ó $\beta \alpha \sigma \mathrm{l}$. If so, the nearest thing to assume would be to connect Karlóva (so accented) with Slavic, as we have seen Kárlovo above. But is $\dot{\eta} \mathrm{K} \alpha \varrho \lambda$ ó $\beta \alpha$ a reality? According to Zafeiriou's statements, the natives of the hamlets Furni and Kondeika in the NW region of the island (to which region Karlovasi also belonged) used, early in the twentieth century, the directional

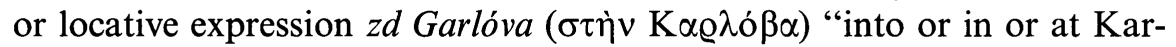
lova" and that $\dot{\eta} \mathrm{K} \alpha \varrho \lambda$ ó $\beta \alpha$ changed gender and became $\tau$ ò $\mathrm{K} \alpha \varrho \lambda$ ó $\beta \alpha \varsigma$ by

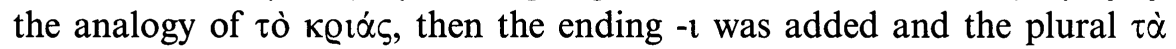

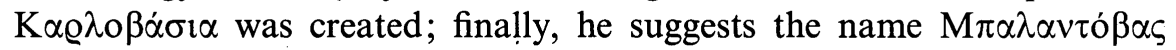
of a village on the Anatolian W. coast opposite Samos as a parallel. 42

The refutation of Zafeiriou's etymology is not difficult because his unproved assumptions are too many and the verification, with evidence, of the chain of changes suggested is impossible.

Starting with Baladovas in Caria, we know that there has been no Slavic influence there and the termination -ovas is certainly Turkish ovast "the plain" with loss of the unaccented $i$ in the Samos dialect; the name is Turkish Balad-ovast. The thought that the Slavic suffix -ova was provided by Greek (Peloponnesian) speakers in the sixteenth century falsely assumes the productivity of that Slavic suffix in the speech of Greek speakers, which is neither evident nor likely. 43 Then for the derivative Karlóva the author

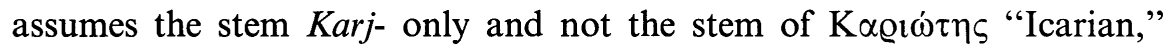
when we would expect ${ }^{*} \mathrm{~K} \alpha \varrho \omega^{\prime} \tau \beta \beta \alpha$. The alleged change $r j$ into $r l$ in $\mathrm{K} \alpha \varrho \lambda$ ó $\beta \alpha \varsigma$ from $K \alpha \varrho j o ́ \beta \alpha \varsigma^{44}$ is impossible and excluded. ${ }^{45}$ And, while

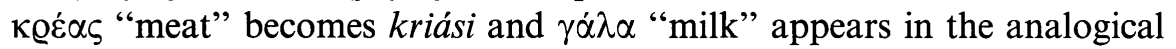
form $\gamma$ álas, the case of $\mathrm{K} \alpha \varrho \lambda \mathrm{o} \beta \alpha \varsigma \rightarrow \mathrm{K} \alpha \varrho \lambda$ ó $\beta \alpha \sigma \mathrm{l}$ is different: $\mathrm{K} \alpha \varrho \lambda \dot{\beta} \beta \alpha \sigma \mathrm{l}$ is a name with no meaning attached to it and has no association with similar synonymic or antonymic notions; e.g. $\dot{\eta}$ Пó $q \tau \alpha, \dot{\eta} K \alpha \lambda i \tau \sigma \alpha$,

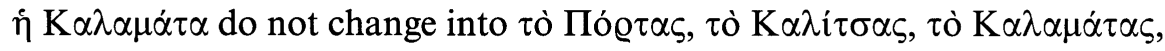
etc., not even in the Samos speech.

My conclusion is that the quasi-Slavic etymology of Karlovasi is improbable, nay impossible, and as such has to be unequivocally discarded. What, however, remains is to explain the accusative form $d$ Garlóva

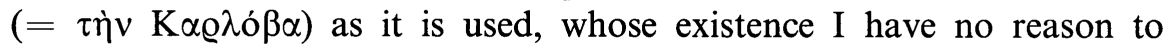
question.

\footnotetext{
42 Zafeiriou, $A \Sigma 1.221$.

43 Max Vasmer, Die Slaven in Griechenland (Berlin, 1941), did not list any Slavic placenames from the islands Lemnos, Lesbos, Chios, Samos, Icaria, and the Dodecanesus.

44 Zafeiriou, $A \Sigma 3$ (1948-54), 165-198; the alleged change on p. 192.

45 The alleged phonologic changes of $r j \rightarrow r l j \rightarrow r l$ (Kárjova $\rightarrow$ Kárljova $\rightarrow$ Kárlova) are not normal for Modern Greek or for the Samian dialect.
} 
I offer here an explanation of the form $\mathrm{K} \alpha \varrho \lambda$ ó $\beta \alpha$ in lack of a better one. The local pronunciation of the name was tu karlóvas (local dialectal for to Karlóvasi, used especially as the accusative form; some speakers, misled by the flexional patterns in the local dialect, mistook tu karlóvas as $t$ 's karlóvas $\left(=\tau \tilde{\eta} \varsigma \mathrm{K} \alpha \varrho \lambda \mathrm{ó}_{\beta} \alpha \varsigma\right)$ and formed a new accusative t'n karlóva $\rightarrow d(n)$ garlóva ( $\tau \dot{\eta} v \mathrm{~K} \alpha \varrho \lambda o ́ \beta \alpha$ ). This may be necessary to postulate because the form $\mathrm{K} \alpha \varrho \lambda \mathrm{o} \beta \alpha \mathrm{f}$. (for $\mathrm{K} \alpha \varrho \lambda \hat{o} \beta \alpha \sigma \mathrm{l}$ ) is confined to a very small area, the $\mathrm{NW}$ region of the island, and it bears the accent on the same syllable as does the full form Karlóvasi, whereas the reverse procedure from $\dot{\eta} \mathrm{K} \alpha \mathrm{\alpha}-$

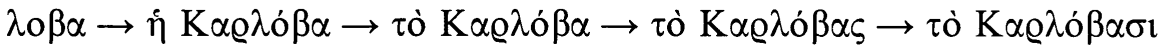
postulates four, i.e. too many, imaginary and unwarranted changes.

Another solution would be to assume that tò $\mathrm{K} \alpha \varrho \lambda$ ó $\beta \alpha \sigma \mathrm{l}$ changed gender into $\dot{\eta} \mathrm{K} \alpha \varrho \lambda$ ó $\beta \alpha \sigma \eta$ in the NW regional speech by accommodating the foreign name Karlovast to the feminine since it applied first to the plain which is represented in Greek by a fem. noun $\pi \varepsilon \delta i \alpha \dot{\alpha} \alpha$ or $\lambda \dot{\alpha} \kappa \kappa \alpha$; thus $\dot{\eta} \mathrm{K} \alpha \varrho \lambda$ ó $\beta \alpha \sigma \eta$, locally karlóvas, could have been transformed into $\mathrm{K} \alpha \varrho \lambda$ ó $\beta \alpha$. But this solution is not probable because "the plain" is $\delta$ $\kappa \alpha \dot{\mu} \mu \pi \varsigma_{\varsigma}$ (masculine noun) in Samos and this particular plain is called

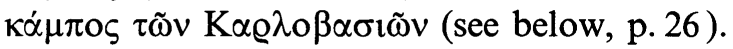

\section{GREEK}

In endeavoring to find the etymon of the name, Greek possibilities had to be explored, even if at first sight such a solution seemed a priori improbable.

The first test would be whether the form of the word can at all be Greek; here, my conclusion was that either the name must have come originally from another language because of its appearance karlóvasi (sísi), that is

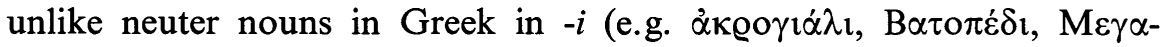

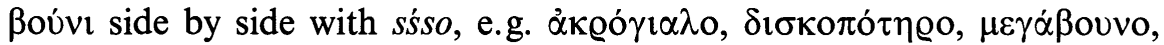

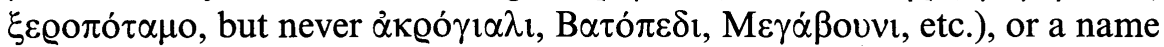
form in $-i$ transformed from a genitive-derived name $\tau$ oṽ $\mathrm{K} \alpha \varrho \lambda o ́ \beta \alpha \sigma \eta$,

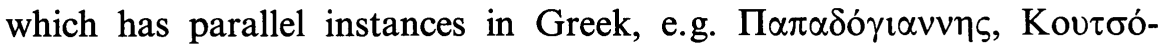
$\gamma \mathrm{i} \varrho \gamma \alpha \varsigma$, etc., if, to be sure, $\mathrm{K} \alpha \varrho \lambda \mathrm{o} \beta \alpha \sigma \eta \varsigma$ had an unassailable origin within Greek itself.

The first aspect of the matter is whether from an anthroponym K $\alpha \varrho \lambda$ ó-

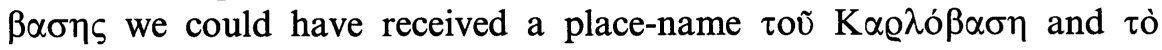
$\mathrm{K} \alpha \varrho \lambda$ ó $\beta \alpha \sigma \mathrm{t}$. In fact, in viewing both today's family names in the Karlovasi area and the toponyms recorded from the same area, we do find toponyms that match the family names and derive from the latter; there follow seven pairs (the abbreviations are $M . K .=$ Meseo Karlovasi and $N . K .=$ Neo Karlovasi): 
Family name

'A $\gamma \alpha \pi \eta \tau o ́ \varsigma(N . K$.

Kov $\alpha \lambda i \delta \eta \varsigma$ (N.K.)

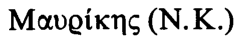

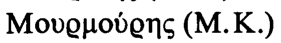

Nikń $\alpha \varsigma$ (N.K.)

$\Sigma \alpha \varrho \iota \alpha \nu o ́ \lambda \eta \varsigma$ (N.K.)

$\Sigma \pi \alpha v o ́ \varsigma(\mathrm{M} . \mathrm{K}$.)
Derivative toponym

oi 'A $\gamma \alpha \pi \eta \tau \alpha$ ĩo

$\tau \dot{\alpha} \operatorname{Kov} \tau \alpha \lambda i \delta ı \kappa \alpha$

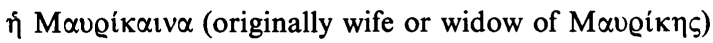

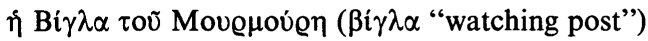

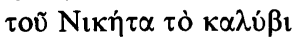

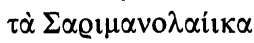

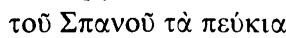

An internal Greek explanation of Karlóvasi would, in this respect, be

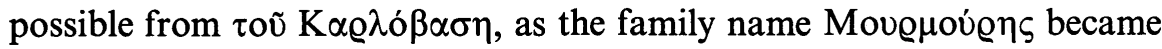

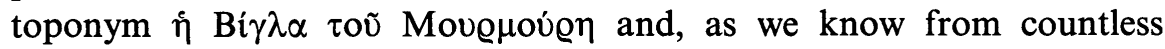

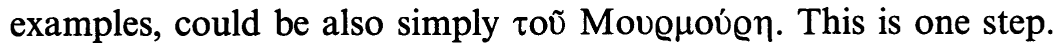

Further, with the aid of the lists of family names in the Karlovasi area, I tried to ascertain whether or not a family name was the basis of naming the place. $\mathrm{K} \alpha \varrho \lambda \alpha \varsigma$ is the name of a family in Meseo Karlovasi but represents a domestic immigrant into Karlovasi from Marathokambos of Samos,

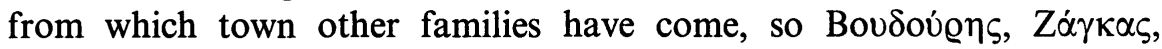

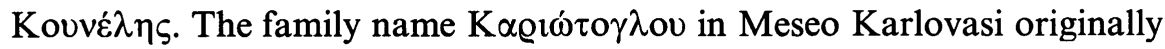
occurred in Neo Karlovasi (above, p. 15, n. 39) and is not relevant here but is mentioned because it was used by $\mathrm{N}$. Zafeiriou in developing his etymological theory.

At best, one could suggest a name $\mathrm{K} \alpha \mathrm{Q} \lambda \dot{\beta} \beta \alpha \sigma \eta \zeta$ or $\mathrm{K} \alpha \varrho \lambda \mathrm{o} \beta \dot{\alpha} \sigma \eta \zeta$, compounded name of $\mathrm{K} \dot{\alpha} \varrho \lambda \mathrm{\alpha}$ and $\mathrm{B} \alpha \dot{\alpha} \sigma \zeta$, but we should be aware of the fact that such a name is only a reconstruction (though very well possible). Details are relegated here to small print.

\section{$\operatorname{KAP} \Lambda \mathrm{O} \Sigma$}

The name Kó $\propto \lambda \propto \varsigma$ as a given name in Greek derived from Italian Carlo (this being a variant of Carolo) and occurs as such primarily in Greek areas where Italian influence is historically expected, so in Andros, Syros (here even diminutive $\mathrm{K} \alpha \varrho \lambda \dot{\alpha} \kappa \mathrm{l}$ ), and Kephallenia. ${ }^{46}$ Hence derives the surname in Athens, Andros, Keos, Syros (sixteenth cent.), Rhodes, Tenos, Siphnos, Kerkyra, etc. (the form K $\alpha \varrho \circ \lambda \circ \varsigma$ of the surname also occurs); the earliest recorded case of the surname $\mathrm{K} \alpha \varrho \lambda o \zeta$ is possibly that of a bibliographer of the early sixteenth century (1516, Nafpaktos); in modern Greece the surname K $\alpha \varrho \lambda o \varsigma$ continues, so in Athens.

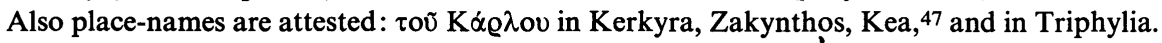
The form $\mathrm{K} \alpha \varrho \lambda \alpha \zeta$ as surname, attested in Samos (as noted above) is obviously from Italian

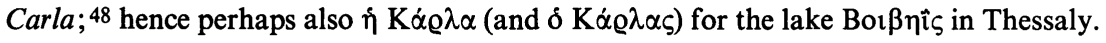

$\mathrm{K} \alpha \varrho \lambda$ ovi $\sigma_{\mathrm{r}}$ "island of Carlo" for a round island close to Astakos of Aitoloakarnania, for a deserted islet near Ithaca not far from Lefkada, and (with a byform K $\alpha \lambda \circ v \eta \dot{ } \sigma$ ) the SE islet of three (called $\mathrm{K} \alpha \lambda \dot{\alpha} \mathrm{N} \eta \sigma i \dot{\alpha}$ ), being one of the extant groups of 25 Echinades (previously 33 , eight of which have been silted in).

\footnotetext{
46 Kahane, Italienische Ortsnamen (1940), 272.

47 Ibid., loc. cit.

48 Kahane, op. cit., 273, did not include the fem. given name K $\alpha \varrho \lambda \alpha$.
} 


\section{$\mathrm{BA} \Sigma \mathrm{H} \Sigma$}

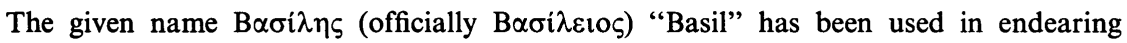

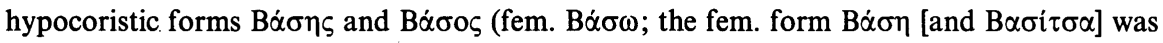
recorded in the speech of Skopos [Thrace]) are common and used also in Samos. B $\alpha \sigma \sigma \zeta$ as surname occurs in Crete ${ }^{49}$ and other parts of Greece and is possibly built-in in compounded names in $-\beta \dot{\alpha} \sigma \eta \zeta$ and other such names; the name form $B \dot{\alpha} \sigma o \zeta$ is found as a family name also elsewhere in Greece and in Neo Karlovasi.

\section{$\operatorname{KAP} \Lambda \mathrm{OBA} \Sigma \mathrm{H} \Sigma$ ?}

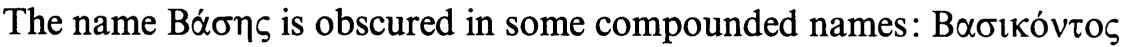

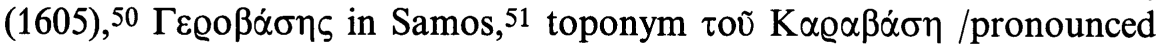
karavás / in Messenia.52 These names are very probably compounded from

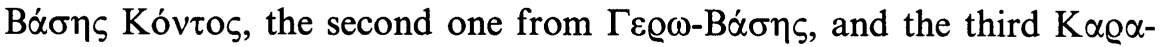

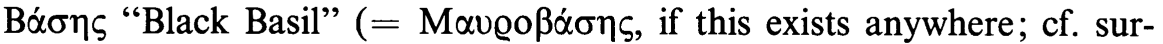

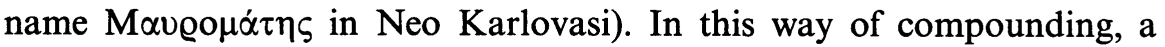

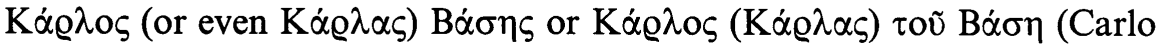
son of Vasis) would become surname *K $\alpha \varrho \lambda \circ \beta \dot{\alpha} \sigma \eta \zeta$. It would be an anthroponym that emerged from a hypostasized compound, which existent parallels warrant, and such names are traceable back into the usage of the Middle Ages. 53

Our concern about the accent lying on the antepenult in ${ }^{*} \mathrm{~K} \alpha \varrho \lambda \dot{o} \beta \alpha \sigma \eta \varsigma$ may be removed by one parallel I am able to draw: a district in Argos

49 Vassi: S. Lambros, NE 10.455.

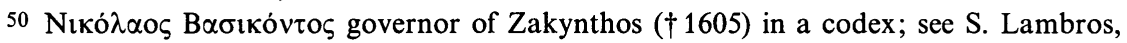

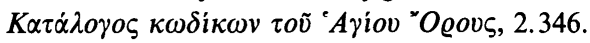

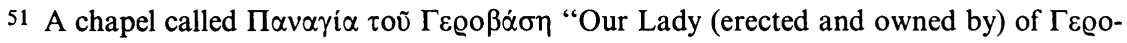

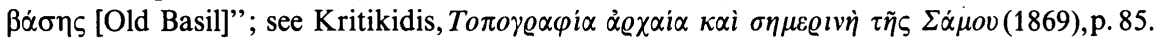

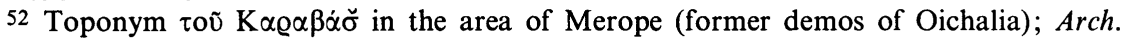
Hist. Lex., ms. 628, p. 47. - Surnames with $\kappa \alpha \varrho \alpha-$ are attested in Samos: K $\alpha \varrho \alpha \sigma \tau \alpha \theta \eta \bar{s}$

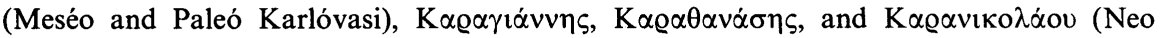
Karlovasi).

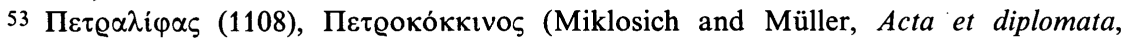

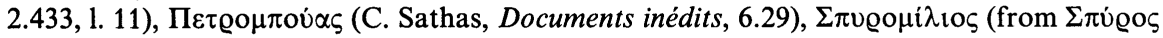

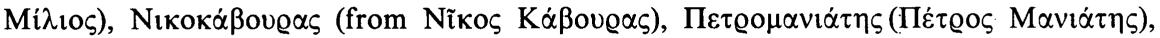

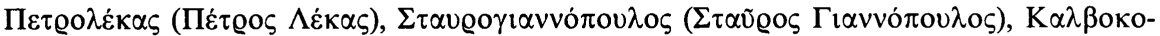

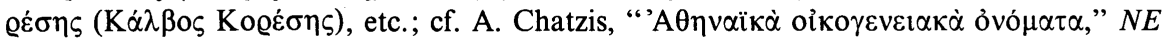
19 (1925), $323 \mathrm{f}$.

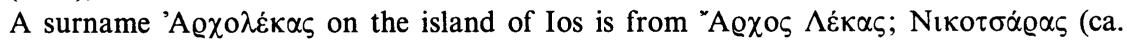

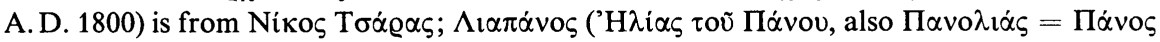

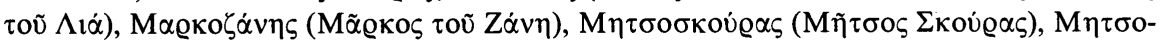

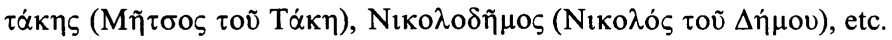

In the village Vlaka (renamed Chrysochori) of Triphylia (Messenia, Peloponnesus) there

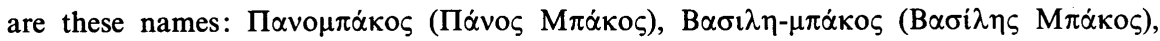

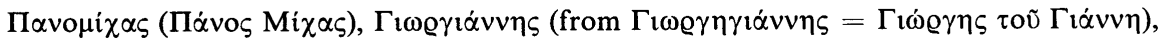

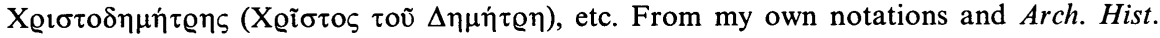
Lex., ms. 628, pp. 7 and 80 . 


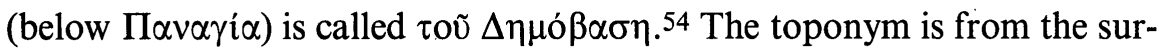

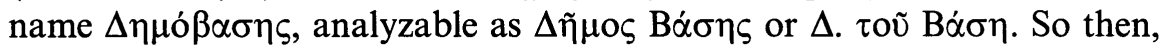
the form so accented is possible.

In conclusion, our effort to set up a name $\mathrm{K} \alpha \varrho \lambda$ ó $\beta \alpha \sigma \eta \zeta$ is in part vindicated but the name is still hypothetical and we need a definitive explanation; though the above explanation in need would be, under the circumstances, a good one, if another more convincing one is established the foregoing has to be ignored.

\section{TURKISH}

Several writers, two of them Samians, Emmanuel Kritikidis (1869) and Epameinondas Stamatiadis (1886), suggested a Turkish explanation of the name Karlovasi. The century-old explanation was accepted by L. Bürchner and others but opposed by Nikolaos I. Zafeiriou. The suggestion deserves detailed discussion.

Karlovasi would be from $\kappa \alpha \varrho \lambda i$ ỏ $\beta \alpha \sigma i$ "snowed over, snowcovered plain," according to Kritikidis. ${ }^{55}$ According to Stamatiadis, the Turks

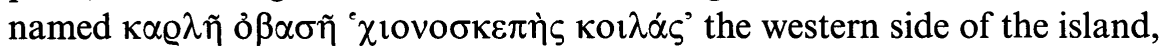
where the whitened trees appeared from afar like a snow covered valley. 56 L. Bürchner and others follow suit, 57 so that we may state that the Turkish origin of the name has won general acceptance. Another Samian, Nikolaos I. Zafeiriou, who gives no references to his predecessors, attempts to refute the explanation with these arguments: (a) the earliest Karlovasi was not located on the plain but on a hill (200 $\mathrm{m}$ high) and (b) since the first settlers and inhabitants of old Karlovasi were Icarians, the namegivers were not Turks. 58 The argumentation of Zafeiriou, however, is not solid. The plain is important for the people who lived nearby but because of the piratic plague they had to hide their abodes away from the sea; in any case, the plain may not have waited for the settlers to come in the sixteenth century to be named by them. The conclusion drawn from this premise to preclude Turkish naming in any case is false because it lacks evidence, whereas the name itself constitutes evidence, is there, but should be interpreted; that is the crux of the matter.

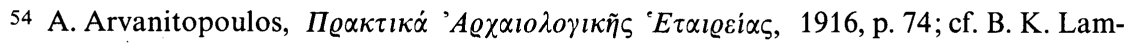

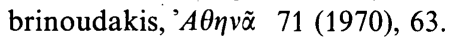

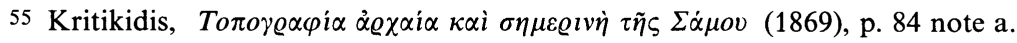

56 Stamatiadis, $\Sigma \alpha \mu l \alpha \kappa \dot{\alpha} 4$ (1886), p. 17.

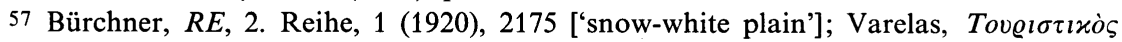

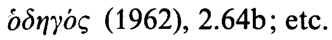

58 Zafeiriou, $A \Sigma 1$ (1948), $220 \mathrm{f}$. - Zafeiriou here goes so far as to dare to suggest, albeit as a question, that people from Karlovasi gave the name Baladovas to a village on the western coast of Asia Minor, opposite Samos; this is sheer speculation and rests on absolutely no evidence.
} 
Difficulties in accepting the Turkish solution were, to my mind, (a) the form Karlovasi from karlı ova, not K $\alpha \varrho \lambda$ ıó $\beta \alpha \sigma \iota$ (karljóvasi), as expected in Greek; yet the compounding had obviously been made in Turkish and, indeed, there is Turkish Karlova as a county in the province of Bingöl; 59 but this is actually no problem, as explained by Professor Tietze (see below, p. 28 ); and (b) the realia, namely the fact that on a low seacoast (ca. $40 \mathrm{~m}$ high) snow was probably a rare thing; however, naming is not a straight-line operation and we miss here the procedure of naming, but still the name is there, although it needs not mishandling but an authentic interpretation.

What, however, renders our situation easier in advancing toward the true explanation is the fact that, though I was unable, in spite of persistent search, to locate a place-name Karlovast in Asia Minor, a welcome K $\alpha Q-$ $\lambda o ́ \beta \alpha \sigma \mathrm{l}$ turned up in Greek Macedonia. We shall see the rest below, in part III: The Interpretation.

\section{KARLOVASI IN MACEDONIA;}

an old, effaced, and rediscovered name.

\section{HISTORICAL BACKGROUND \& DESCRIPTION}

A hamlet in the nomos of Kilkis in Macedonia was in 1928-29 re-

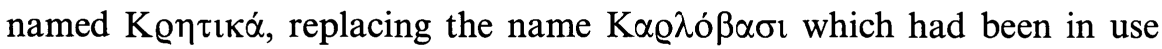
until 1929. Karlovasi and Erdzeli (or Eretseli) renamed 'A $\lambda \varepsilon \xi \dot{\alpha} v \delta \varrho \alpha$ (1940), now constitute one village; these along with a nearby hamlet called Pulamasl were constituents of the community of Mouries (formerly Akindzali) up to 1934; since then they are part of the community

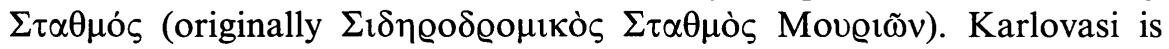
situated at an elevation of $128 \mathrm{~m}$ at the foot and SW of Mt Beles ca. $2.5 \mathrm{~km}$ from the Railway Station ( $\Sigma \tau \alpha \theta \mu$ ò $\varsigma$ Mov@iñv). Karlovasi and Erdzeli and all villages in the vicinity are located on the plain between Mt Beles and Kruša. ${ }^{60}$ The population of the area, including Karlovasi

59 See Register of Inhabited Places in Turkey (1946-50), p. 633.

$60 \mathrm{Mt}$ Beles (or Belasitsa) or, according to others, Mt Kruša is identified with anc. Ke@кiv $\eta$ attested by Thucydides 2.98 . Both these mountain names are Slavic and specifically Bulgarian: Beleš (see Vasmer, op. cit. [note 43], 86; cf. M $\pi \dot{\varepsilon} \lambda \varepsilon \sigma \mathrm{l}$ in Greece: Thessaly, Phocis, Argolis, and Gortynia [Vasmer, 94, 117, 127, 156])

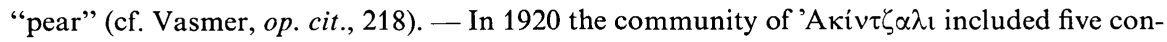

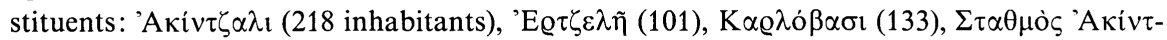

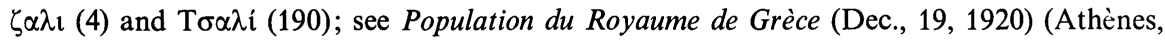
1921), p. $117 \mathrm{f}$. - While to the east is the mountain, north of Karlovasi and Erdzeli are located

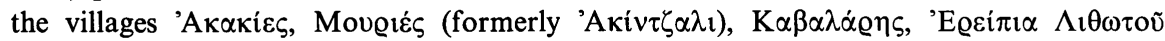

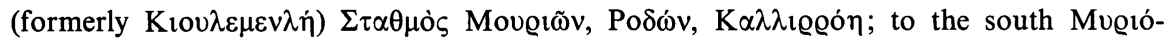

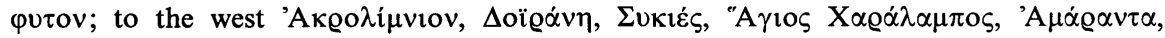

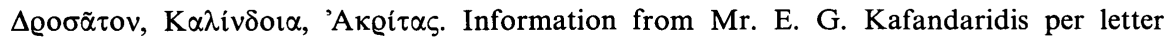
30. I. 1973. 
and Erdzeli, before the exchange of populations in 1923, consisted exclusively of Turkish farmers, who spoke Turkish, and was in its entirety transplanted to Turkey. The new population in Karlovasi since 1923 is Greek and was made up of refugees from Pontos, specifically from Ordu (Kotyora), and from East Thrace, specifically from Saray. ${ }^{61}$

\section{THE STORY OF THE NAMES:

$$
\mathrm{K} \alpha \varrho \lambda \hat{\beta} \beta \alpha \sigma \mathrm{\imath}=\mathrm{K} \varrho \eta \tau \iota \kappa \alpha ́
$$

While in Samos no one tried or succeeded in renaming the place Karlóvasi, entrenched as it has been in the history and language of the people, partly because its Turkish origin was rejected, the fortunes of the Kilkis area were different during World War I and had as an outcome, among other vital matters, the renaming of many hamlets which had been up to 1923 solidly inhabited by Turkish people.

In the attack and battle of Greek forces against the Germans and Bulgarians in September (18-30) 1918 which ended in the liberation of Doyrani, Greek losses were heavy: 500 dead and 2,600 wounded; of these casualties, the IV Cretan division under General Spiliadis suffered the loss of 613 officers and men. ${ }^{62}$ To honor the memory of the Cretans who fell in battle, the village $\mathrm{K} \alpha \varrho \lambda \hat{\beta} \beta \alpha \sigma \iota$ was renamed $\tau \dot{\alpha} \mathrm{K} \varrho \eta \tau \iota \kappa \alpha ́$ during the year 1928-29 and a memorial to the fallen was erected at $\Sigma \tau \alpha \theta \mu$ ò $\varsigma$ Mov@iñv.

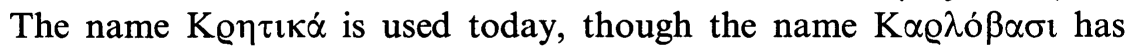
not been forgotten, but both disappeared from official papers. ${ }^{63}$ The curious but understandable thing is that, as with numerous new names replacing earlier ones in Greece, the patrial (or inhabitant) name is

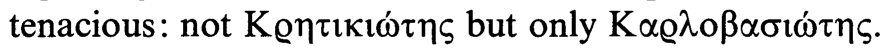

\section{ATTEMPTS at explanation}

As in the case of Karlovasi in Samos, the Slavic explanation is advanced to explain Karlovasi in the nomos of Kilkis. Mr. N. Arvanitidis, a native of Karlovasi-Kritika, voiced to Professor Demetrios Petropoulos his view that the name is Bulgarian. The idea certainly comes from the fact that the Slavic neighbors in the north could have been the name-

61 Information from Mr. Kafandaridis (see preceding note).

62 Information from Mr. A. Drilias and Mr. E. Kafandaridis.

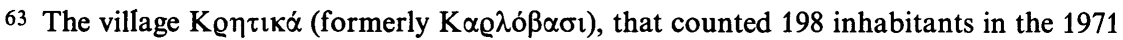
census, became part of the village 'A $\lambda \varepsilon \xi \dot{\alpha} v \delta \varrho \alpha$ between 1934 and 1940; Stoicheia 25 (1962), p. 114 and 115. The two names are still listed in the index of that volume (p. 198 and 200) but

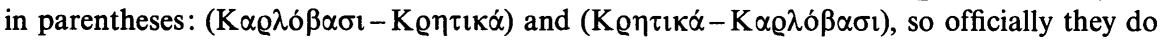
not exist. But, as long as people remember, at least $\mathrm{K} \alpha \varrho \lambda$ ó $\beta \alpha \sigma \mathrm{t}$ will not be forgotten on account of the persisting patrial $\mathrm{K} \alpha \varrho \lambda \mathrm{o} \beta \alpha \sigma i \omega \dot{\tau}\rceil$. 
givers. If the name were Karlova, it could be, but the form Karlóvasi cannot be explained from Slavic, including Bulgarian.

My repeated inquiries about a surname $\mathrm{K} \alpha \varrho \lambda o ́ \beta \alpha \sigma \eta \varsigma$ in Macedonia to establish the possibility of a Greek name K $\alpha \varrho \lambda$ ó $\beta \alpha \sigma \eta \zeta$, as discussed above (p. 19f.), were answered in the negative. Therefore this possibility is also out of the question.

On account of the Turkish population in and around Karlovasi and the

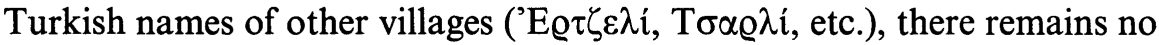
alternative but the solution proposed below.

\section{THE INTERPRETATION OF THE NAMES}

The interpretation of the names is not equivalent to an opinion, however splendid or likely that opinion may seem to be, when the assertion is not proved with evidence; interpretation is an explanation adequately documented in all possible details. Here follows the interpretation of $\mathrm{K} \alpha \mathrm{Q} \lambda \mathrm{o}$ $\beta \alpha \sigma$, the name shared by the formerly Turkish village Karlovasi in the nomos of Kilkis and by the Greek settlement Karlovasi in Samos.

The existence of a second independent Karlovasi in mainland Greek territory renders the task of the name's interpretation easier and safer, since at the same time it is established that neither was Karlovasi in Samos settled by Macedonian people of Kilkis nor had Karlovasi in the latter area ever received settlers from Samos. It is evident that the name Karlovasi in the two widely separated areas necessarily was given independently.

Common in both areas are well-known facts:

1) Turkokratia held sway in Macedonia and in Samos for centuries and there still exist or there existed in the past names of inhabited places of unequivocally Turkish origin; 64

${ }^{64}$ Let there be mentioned the following place-names in Samos: Domúz burnú (earlier Donguz burnl "cape of the boar," recorded in the sixteenth cent.), a cape at the E end of

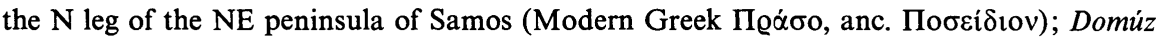
Dağ also in Caria (map of K. Lycker in Philippson, Das südliche Ionien [1936]) and Domusbergas on the S side of Mycale (Philippson's Geologische Karte des westlichen Kleinasien, Blatt 3, in his Reisen und Forschungen II: Ionien und das westliche Lydien [1911], at end);

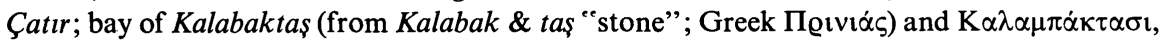
pronounced $K \alpha \lambda \alpha \mu \pi \alpha \dot{\alpha} \tau \alpha \sigma \mathrm{l}$ (community since 1918; renamed $\mathrm{K} \alpha \lambda \lambda \mathrm{l} \theta \dot{\varepsilon} \alpha$ in 1950, with 472 inhabitants, $300 \mathrm{~m}$ high); plural $\mathrm{K} \alpha \lambda \alpha \mu \pi \alpha \kappa \tau \alpha \dot{\alpha} \alpha \alpha$, area in the W. of Samos; the кotvó $\tau \eta \zeta$ $\mathrm{K} \alpha \lambda \alpha \mu \pi \alpha \kappa \tau \alpha \sigma i \omega v$ consists of three settlements (Kalabaktaş, "A $\gamma 10 \varsigma^{\prime} \mathrm{I} \sigma i \delta \omega \varrho \circ$, and $\Pi \lambda \dot{\alpha} \alpha \alpha$ );

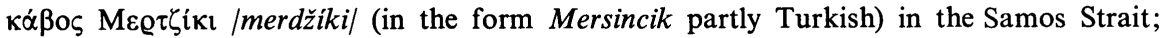

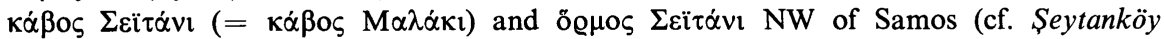
"Devil's village" in Kyzikos peninsula and Mysia; Philippson, Reisen und Forschungen 1

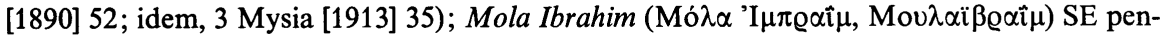

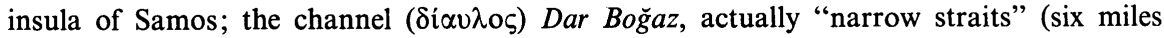


2) the two places are located on low plains (Turkish ova "low plain, lowland," ovast "its low plain, its lowland");

3) both have to do with snow (Turkish kar "snow," karll "covered with snow"). In the Kilkis area the Beles mountain-range is covered with snow during the entire winter period and on the plain and in Karlovasi snow falls during the three-month winter (December-February). In the Samos Karlovasi plain snow is not visible as much as in Northern Greece and Macedonia but the name clearly indicated its identity with "snow"

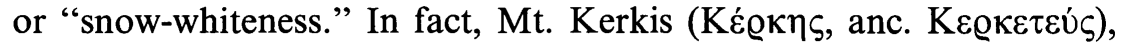
ca. $1,440 \mathrm{~m}$ high, is covered with snow for months, and then also Karlovasi is cold. 65

The name Karlovasi in Macedonia may give us some more corroboration; it is accented by the older local speakers on the ultima $\mathrm{K} \alpha \varrho \lambda \circ \beta \alpha \sigma i 66$ and that is the general Turkish way of accentuation; it should be recalled that the present inhabitants are Greeks who replaced the Turkish population in 1923 but these Greek speakers also know Turkish because they were transplanted here from East Thrace and Pontos, where they lived among Turks.

From these facts naturally arises the inevitable conclusion that the namers in the case of the two widely separated places were Turkish speakers. However, there remain two more steps to round out the interpretation: the explanation of the name Karlovast within Turkish and Turkish parallels in Asia Minor, specifically in the area opposite the island of Samos.

\section{The Turkish Name}

Karlovasí is a compound of adj. karl "snow-covered" and ova (and -ovast) "plain." The analysis of the name established beyond doubt its Turkish origin.

The first member of the compound occurs as an independent place-name as well as in compounded names. Thus,

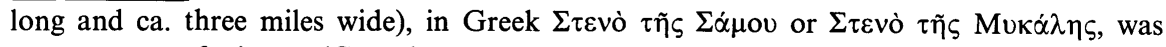
a great nest of pirates (Georgirenes, A Description, p. 4); Mt Mycale is Turk. Samsun Dağ and Mod. Gr. K $\alpha \mu \eta \dot{\lambda} \lambda \alpha$ "camel" (Lykoudis, MEE 2 [1927], 389c); the latter, though no

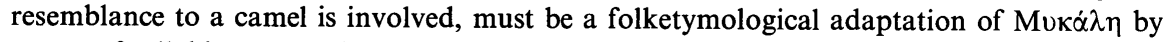
means of syllabic transposition: mikáli $\rightarrow$ kamila, because Mvкá $\lambda \eta$ offered no etymological sense; cf. Susam adası folketymol. with susam $\leftarrow \sigma \eta \sigma \alpha \dot{\mu l}$; above, p. 8.

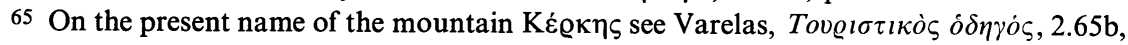
$66 \mathrm{~b}, 67 \mathrm{a}, 67 \mathrm{~b}$. On snow and weather, as presented in the last sentence in the text above, K. Ptinis per letter of 20. III. 1972.

66 Information from Mr. E. Kafandaridis (Mikrovrysi, Kilkis) per letter 18. II. 1972. 
Karl, name of 14 villages (two of them renamed from earlier Norşen and Befriçan); the Greeks pronounced $\mathrm{K} \alpha \mathrm{Q} \lambda i$ the one in the area of Didymoteicho and Greek officials had renamed it Xıová $\delta \varepsilon \varsigma ;$

Karlu, name of two places, one in Çanakkale and the other in Samsun; Karlıköy, name of a place in the areas of Kesani, Saranda Ekklisies and Serres;

Karlipinar, name of a village in the area of Kayser;

Karlitepe, name of a place in Ünye (Oivón) of Ordu (Kotyora);

Karlova, name of a county in the province Bingöl.

There are more compounded new names of renamed villages. 67

The second member of Karlovast is ova "plain": Ova occurs as an independent name of 13 settlements, 68 also derivative ovack "little plain" as name $O v a c t k$ of 51 settlements and three Ovackk compounds, 69 but also 43 Ova-compounds such as Ovabası, Ovaköy, Ovapinar, etc. 70

In view of this material, it becomes evident that karl ova became Karliova ${ }^{71} \rightarrow$ Karlova, from which resulted the form Karlovast. The element (or ending) -sl in -ovast was explained by Professor Tietze and I may summarize his response here: the element $-\imath,-i,-u,-\ddot{u}$ after consonants and $-s l$, $-s i,-s u$, -sü after vowels is originally the 3 rd person possessive "his, its" and is attached to nouns, e.g. dă̆ "mountain" : dă̆ "its mountain," göl "lake" : gölü "its lake," ada "island" : adasl "its island"; according to a principle dominant in Turkish, a noun compounded of noun + noun requires the possessive element attached to the second noun, 72 so Susamadast "Samos-island," etc. In the meantime I was able to study the article on compounded nouns in Turkish by the late Professor Jean Deny and see that the possessive element $-s l$ appears also in toponyms, so Değirmenderest (eight times) beside Değirmendere (29 times) Kalederest (twice) beside Kaledere (four times)

Yalımahallesi in the province of Trebizond beside Yalımahalle for the sea quarter in a place of the province of Giresun

Kurobası beside Kuroba

Kaleobast (twice) beside Kaleoba

Kırobası beside Kıroba

Taşobast (or a false purism for): Taşoba

Türkobasl : Türkoba73

67 Register of Inhabited Places in Turkey (1950), 633; Köylerimiz (1968), 329.

68 Register (1950), 886.

69 Register 886f.; Köylerimiz, 433.

70 Register 886; Köylerimiz 433, 434.

71 Mentioned above, p. 21.

72 Professor Andreas Tietze (per letter of 4.II.1972); he also adds a similar pattern with a possessive going with the second member of the compound in some southern German dialects. On the Turkish possessive element cf. also Robert, La Carie, 2.32 note 1.

73 J. Deny, BSL 50 (1954), 152-154. 
As Professor Tietze informs me, the phenomenon seen in the foregoing cases, listed by Deny, is the dropping of the suffix $-s l$, whereas in the case of karl ova "snowy plain" $\rightarrow$ Karl-ovast we are confronted with the reverse phenomenon; for karl ova is not a noun-plus-noun compound but an adjective-plus-noun compound, which, according to the Turkish grammatical rule, should not have the possessive suffix. There are, however, some erratic exceptions (see below). ${ }^{73^{\mathrm{a}}}$

We shall return to the form of Karlovasi below.

In realia, the second member of the compound -ova "low plain, lowland" (as contrasted to yayla "high plain, plateau") is verified for both place-

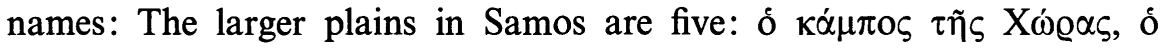

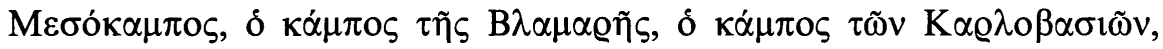

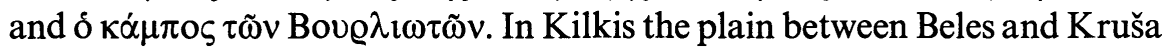
does also verify Karlovası there. It appears therefore, at least to this writer, that it was the plain which was originally named Karlovast in both Samos and Kilkis and subsequently the settlements themselves were so named. This makes sense since the old Karlovasi in Samos is not on the plain (ca. $40 \mathrm{~m}$ high) but higher $(200 \mathrm{~m})$ on a hill and the Karlovasi in Kilkis is at the foot of the mountain.

To the realia belongs also the geographic (and geologic) closeness of Samos to the NW Carian area of western Asia Minor and the identical naming patterns that occur in that area.

Pasa-ovast is another name in Samos, ${ }^{74}$ probably from Turk. Paşaovasl. Baladovast "plain of Balad," name of the lowlands, especially on the northern side of the lowest section of the Meander River, in Greek M $\pi \alpha \lambda \alpha \nu$ -

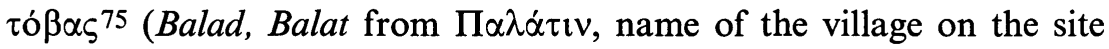
of anc. Miletus). It is located in the plain in Asia Minor, opposite the strait east from Vathy as the crow flies, more precisely near Söke (Sokya) (Solakuşağı) and the village Kuşadası (Kuş̧̧uburnu). ${ }^{76}$

Other parallels in Caria are listed below:

Karayükovasl, a plain area (Karayük-plain);77

Barzovast and Barzaovası, plain region: Barza; 78

$7^{\text {73a }}$ Professor Tietze per letter dated 6.XI.1973. Cf. also below, p. 28.

74 Stamatiadis, $\Sigma \alpha \mu l \alpha \kappa \dot{\alpha} 2$ (1881),7.

75 Zafeiriou, $A \Sigma 1$ (1946), 221. - The author suggests, albeit as a question, that Karlovasi people were the name-givers of $M \pi \alpha \lambda \alpha v \tau o ́ \beta \alpha \varsigma$, which cannot be in any way justified; one may look at a map to see that Karlovasi is located in the NW part of Samos, far from the coast of Asia Minor; a second reason is that it is not apparent why the Karlovasi Greek people would create from Balad- a compound Baladovast; the rest of the reasons may be lumped together in the expression "linguistically and otherwise impossible."

76 K. Ptinis per letter of 20. III.1972. I have been able to verify Söke and Kuşadasl (the latter name being also one for the gulf and the district).

77 Robert, Carie 2 (1954), 77, 149; and map (planche LXV).

78 Ibid., 2.32 note 1. 
Çukurovast: south of the Meander; from this plain the river Kadmos flows; 79

Dombay-ovast "plain of buffaloes" near Apamea; 80

Eşkereovası 81 "open plain"; Eskere-Çukuru-ovasi in S. Caria $(650 \mathrm{~m}$

high); 82 Tietze finds improbable eșkere- (from Persian äshikāre) and

it looks to him like an originally Greek place-name (per letter of 22. III.

1972); in other words, loan-translation of П $\alpha \lambda$ ıóк $\alpha \mu \pi \mathrm{s}$;

Incirliova (from incirli "having figtrees" and ova) west of Aydin;83

Davasovast (900 m high); 84

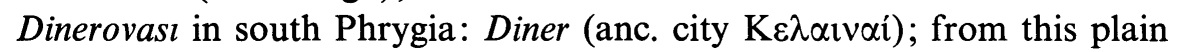

the river Buyuk-Mendere-su flows; 85

Gencerovast (beside Gencerdağ). 86

Further examples are the following from Asia Minor:

Burçakovası, a plain in the area of Tabala

Çulovasi, a mountain; 87

Clmovasl, a great valley stretch that comes from Smyrna and narrows into

a short valley stretch north of Ayasoluk; 88

Cumaovast, a subdistrict in the county Merkez of the province Izmir; 89

Pambuk-ovasl, a plain at the lower course of Kestros in Lycia;90

Pasin-ovasl, a plain to the east of Sivas in Asia Minor (thirteenth cent.); 91

$\Sigma o \lambda o v \tau \zeta o$ $\beta \alpha \sigma \iota$ in the Taurus (Karolidis), Suludjaova near Enegil (Kiepert); mentioned as a Pontic colony. 92

79 Ibid., 2.43; Philippson, Geologische Karte des westlichen Kleinasien, Blatt 6, PM Ergänzungsheft 183 (1915).

80 Robert, Carie 2.82 note 8; idem, Noms indigènes (1963), 355 note 4; Philippson, Geologische Karte des westlichen Kleinasien, Blatt 4, in his Reisen und Forschungen 4 (1914), $P M$ Ergänzungsheft Nr. 180.

81 Robert, Carie 2.37, 357, 359; probably not with -s-, as Robert.

82 Philippson, Reisen und Forschungen 5 (1915), 114.

83 Robert, Carie 2.40.

84 Philippson, op. cit., 124; idem, Geologische Karte des westlichen Kleinasien, Blatt 4, as above note 80 .

85 Philippson, Geologische Karte des westlichen Kleinasien, Blatt 4, as above note 80 .

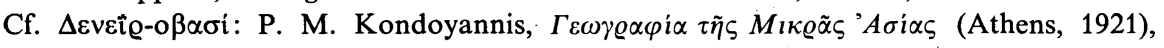
p. 28.

86 Philippson, loc. cit.; Reisen und Forschungen 5 (1915).

87 See the map (plate XXXVI) in E. Honigmann, "Sur quelques évêchés d'Asie Mineure," Byzantion 10 (1935), facing page 644.

88 Philippson, Reisen und Forschungen, II: Ionien und das westliche Lydien (1911), PM Ergänzungsheft 172, p. 30, 33 note 1, 52.

89 Register of Inhabited Places in Turkey 1 (1946), 24; Köylerimiz (1968), 747.

90 R. Heberdey, "Nisa und Komba, zwei Städte der lykischen Milyas," Beiträge zur alten Geschichte und Geographie. Festschrift für Heinrich Kiepert (Berlin, 1898), 158.

91 F. Taeschner, $C M H 4,1$ (1966), 758.

92 I. S. Archelaos, 'H $\Sigma_{l v \alpha \sigma o ́}$ (Athens, 1899), 133. Cf. Dawkins, Modern Greek in Asia Minor (1916), p. 7. 
Some of the foregoing examples display the loss of the vowel preceding -ovast, as does Karlovası from karlı and ova, but, as Professor Tietze tells me, there is no difficulty from the point of view of Turkish in the crasis $l i+o v \rightarrow l o v$ (per letter of 22. III. 1972). Interestingly enough, also aov becomes $o v$ in Barzovasi side by side with Barzaovasi, Sulucaova beside Solucovast, possibly Cimovası beside Cumaovast.

Professor Tietze informs me that the compounds of noun + noun receive the element $-s l$ and the compounds with ova (listed above, 30f.) show mostly the noun + noun pattern; the example İncirliova (from incirli "having figtrees" and ova) has the same pattern as karl ova and does not appear as Incirliovası. Then Professor Tietze goes on: "There are erratic and perhaps arbitrary exceptions. Especially in place-names the elision of the possessive ending is frequent... Much more rare is the shift from the unmarked pattern to the marked pattern which is required from the form karlovast. Perhaps it is an analogon characteristic for the Turkish spoken by non-Turks, but this is only a hypothesis, so in your example Sulucaova (the expected correct form) and Sulucaovasi; it may be that Suluca 'somewhat watery' is itself a place-name and the compound Sulucaovast means 'plain of Suluca'" (per letter 22. III. 1972).

The above Turkish explanation of the name Karlóvasi in Samos and Macedonia is possible and even best, if we admit, as Professor Tietze hesitantly suggests, arbitrary exceptions in the compounding of the pattern noun + noun and assume the shift of the unmarked Karliova to marked karliovast or some kind of an analog characteristic for the Turkish speech as spoken by non-Turks, in our case by Greeks. This, I think, is a valid possibility and the case becomes stronger if we visualize the situation of Greek and Turkish speaking people living side by side and communicating with each other, wherein each party uses the language of the other in a defective manner; literacy was not the rule and it is well known that in general Greeks did not learn Turkish in schools to adopt the correct grammatical usage of everyday Turkish during the Turkokratia (1453 early part of this century) in both Samos and Macedonia; they picked up only a smattering of Turkish for absolutely necessary communication.

If the foregoing is, as is hoped, correct, the validity of the principle in onomastics is visible that the name of a plain is used also as the name of the settlement which is erected in the plain or in its vicinity, as much as the name of a hill or mountain becomes that of the settlement founded at its foot or on one of its slopes; thus there are numerous occurrences of the name Bouvós, Bouvó "mountain," and the like as names of settlements;

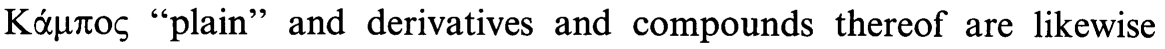
names of settlements. The name K $\alpha \varrho \lambda o ́ \beta \alpha \sigma l$ of Turkish origin is no exception. 
It is hoped that controversial expositions such as this one may serve our younger onomatologists at least as a stimulus toward refining the methods in onomastics and adjacent fields when historical and linguistic contacts are involved.

\section{Professor Tietze's Suggestion}

Captain Piri, an early sixteenth cent. pirate, captain, and naval commander, authored an extensive portulan of the Mediterranean (one version of 1521, published by Paul Kahle, and a later one of 1525 , published in a facsimile reproduction in Istanbul in 1935) and also some maps. Piri describes the island of Samos (183-187), mostly the ports, going clockwise around the island. On the southern shore he mentions in one place areas overgrown with reeds (p. 184): "To the west of that (ruined) castle there is a nice plain. In that plain there is a nice river. It carries water summer and winter and on both sides of it there are huge reedbeds, even natir sticks and düdük [i. e. "pipe" or "whistle"] sticks are found. And east of here is a reedbed [the word used is sazllk], in that reedbed they stir up boars." On the Karlovasi area (p. 185), after coming around Cape Kalabak, he arrives at the river called Karkıllk Çayı on the map (p. 187), flowing east along the north shore and continues (p. 185): "When one goes around the aforementioned cape in eastern direction, there is a large stream facing north. They call that stream Karkllık Çayl [i.e., river of the reeded area]. Very large reeds [the word karkl, karğl means "a stout kind of reed'] grow there, that is to say, natir sticks in particular; not many people go to that place because it is exposed to the northwind, therefore the old ones have time to grow really old, and priceless specimens of sticks are many" [this in Tietze's letter of 4.IV.1972]. The noun karkıllk and (more commonly karğlllk is "reedbed," karğllık çayl "river of the reedbeds," and karğılığ-ovası "plain of the reedbeds"; Dr. Tietze prefers this as the etymon of the toponym [Tietze's letter of 22.III. 1972]. This I may disentangle in stages as follows: ${ }^{*} \mathrm{~K} \alpha \varrho \gamma \imath \lambda \imath \gamma o ́ \beta \alpha \sigma \imath \rightarrow{ }^{*} \mathrm{~K} \alpha \varrho \lambda \imath$ ıó $\beta \alpha \sigma \imath$ (by haplology, i.e. dissimilatory loss of the syllable $\left.g_{l}=\gamma \mathrm{l}\right) \rightarrow{ }^{*} \mathrm{~K} \alpha Q \lambda$ tó $\beta \alpha \sigma \mathrm{l}$ with silencing of the fricative $-\gamma$ intervocalically $\rightarrow \mathrm{K} \alpha \varrho \lambda$ ó $\beta \alpha \sigma \mathrm{r}$ with substitution of the $l$ instead of $l y$. Although these changes are possible, they are not documented.

Dr. Tietze is aware of the fact that the Macedonian homonym is left completely in the dark (22.III.1972). This is so because Karlóvasi in Central Macedonia is not geographically identical with Kirlikova, found in the Ottoman text, i.e. a register of the fiefs of Xanthi and Drama, dated Nov. 4, 1491.93 The name would have meant the village having steppe

93 Fontes Turcici Historiae Bulgaricae, ser. XV-XVI, vol. 2, edited by Nikolai Todorov and Boris Nedkov (Sofia, 1966), p. 476: Krrklıkova, identified by the editors with a village called Karlskovo. [Tietze per letter of 22.XI.1972.] 
character, not cultivated, wild ( $k i r$ "land not under cultivation, steppe," kirllk "not cultivated, having steppe character").

In realia, the stream called Фov@vı

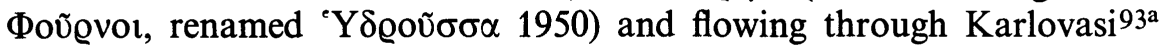
indeed has reedbeds; the reeds are usually made into fishing-rods, whereas in Palio-Karlovasi there are reeds of the common type. ${ }^{94}$ Palio-Karlovasi is situated around a ravine ( $\varrho \varepsilon \mu \alpha \tau i \alpha))^{95}$ that is full of plane trees. I have personally viewed the terrain of Palio-Karlovasi in July 1972 and no reedbeds are visible except for occasional reeds as in places with abundant water. In general, as Mr. Ptinis comments, reeds grow all over the island, and indeed close to the sea.

With regard to the Macedonian toponym Karlovasi, we have the follow-

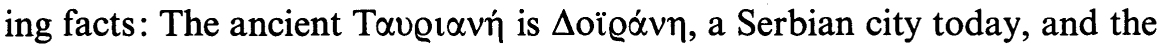

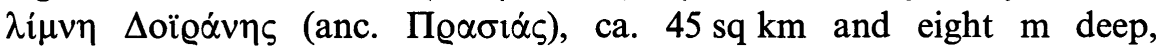
$3 / 5$ Yugoslavian and $2 / 5$ Greek sovereignty, is located on the borders with Yugoslavia (148 m high) and at a distance of six $\mathrm{km}$ from $\mathrm{K} \alpha \varrho \lambda \circ \beta \alpha \sigma i$. Reeds grow on the banks of the lake and close to the town MovQiźs (two $\mathrm{km}$ distant from the lake). 96 The naming, therefore, of the Central Macedonian Karlovasi from the reeds of the Doyrani lake is highly improbable.

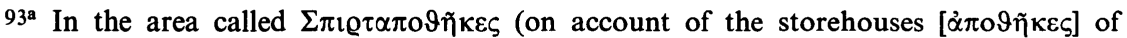
matches and petroleum). Informant was a Karlovasi man in Icaria, reporting to Mr. P. Kourouvanis (latter's letter, 6. XI. 1973).

94 Information from a Karlovasi man who is active in Ayios Kirykos, Icaria, to Mr. Panagiotis Kourouvanis (latter's letter of 26.IV.1972).

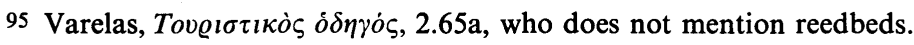

96 Information on the topography, distances, and the growth of reeds from Mr. Kafandaridis (per letter of 13. V.1972).

\section{ADDENDUM}

In bibliography under Piri reis and on p. 29:

Paul Kahle: Piri Re'īs Bahrīje, Das türkische Segelhandbuch für das mittelländische Meer vom Jahre 1521. Berlin und Leipzig, 1926, vol. 1, tables 39-41. A German translation is in vol. 2 (1926), p. 56-60. The "natir sticks" as "Wächterrohr" is wrong; these are "stakes to support a young tree or plant." Dr. Tietze, who gives me this information (per letter of 15. II. 1974), adds that he found the word in a dialect dictionary, recorded in a Cilician village, and that the origin of the term is obscure. 


\section{INDEX}

Greek and non-Greek names involved in discussion are listed. (Abbreviations: $n .=$ note, $w . n .=$ with note.)

'Aк $\alpha \mu \alpha \dot{\alpha} \propto \alpha$ 12, Akamatra 15

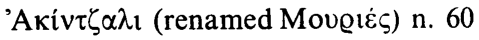

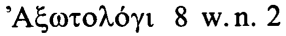

Altın-adası (= Lesbos) 8

'A@ $\beta \alpha v i \tilde{\tau} \varepsilon \varsigma 10$

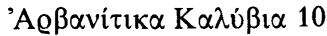

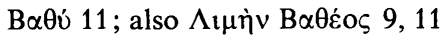

$\mathrm{B} \alpha \dot{\alpha}\rceil \varsigma, \mathrm{B} \dot{\alpha} \sigma o \varsigma 19$

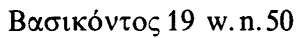

Bouvó etc. 28

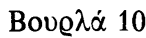

Bov@ $\lambda เ \tilde{\omega} \tau \varepsilon \varsigma 10$

Balad, Balat 26

Baladovas 20 w.n. 58

Baladovas1 (M $\pi \alpha \lambda \alpha v \tau$ ó $\beta \alpha \varsigma)$ 26, n. 75

Barzaovası, Barzovası 26

(Mt.) Beles 21, n. 60

bibliography $2-5$

Burçakovası 27

Carla 18

Carlo 15

Cimovas 27

compounded names; hypostasized - -

19 w.n. 53

Cumaovası 27

Çatır n. 64

Çukurovası 27

Çulovası 27

$\Delta \varepsilon v \varepsilon i \grave{\varrho}-o \beta \alpha \sigma i=$ Dinerovası

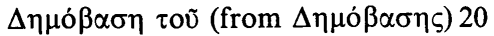

$\delta \eta \tilde{\mu o \zeta ~ K \alpha \varrho \lambda o \beta \alpha ́ \sigma o v ~ n . ~} 31$; - K $\alpha \varrho \lambda \circ \beta \alpha \sigma i \omega v$ 12,13

Dar Boğaz n. 64

Davasovası 27

Dinerovası 27

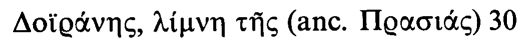

Dombay-ovas 27

Domuz burnu n. 64

Erdzeli 21, n. 60

Eşkereovası 27

exchange of population in Kilkis area

(1923) 21, 22

family names and derivative toponyms 17

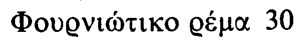

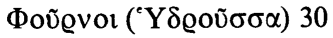

$\Gamma \propto \varrho \gamma \alpha \lambda$ เ $\alpha \operatorname{vos} 11$

Gencerovasi 27

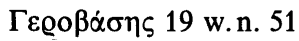

Incirliova 27,28

$-1,-i$, etc. element (possessive suffix) 25 w.n. 72

Kalabaktaş, $\mathrm{K} \alpha \lambda \alpha \mu \pi \dot{\alpha} \kappa \tau \alpha \sigma \mathrm{l},-\alpha \dot{\alpha} \tau \alpha \sigma \mathrm{\imath}$ (renamed $\mathrm{K} \alpha \lambda \lambda_{1} \theta \dot{\varepsilon} \alpha$ ); plur. $\tau \dot{\alpha} \mathrm{K} \alpha \lambda \alpha$ $\mu \pi \alpha \kappa \tau \dot{\alpha} \sigma \iota \alpha$, gen. $-\sigma i \omega v$, n. 64

Kalyvia, K $\alpha \lambda u ́ \beta \iota \alpha 12$

$\mathrm{K} \alpha \mu \dot{\eta} \lambda \alpha(=$ Mycale) n. 64

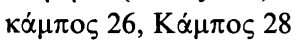

kar (Turk.) "snow" 24

$\kappa \alpha \varrho \alpha$ - surnames n. 52

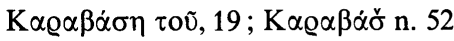

Karayükovası 26

Karğılığ-ovası 33

karğıllı "reedbed," K- 29

${ }^{*} \mathrm{~K} \alpha \varrho \gamma \imath \lambda \iota \gamma o ́ \beta \alpha \sigma \iota 29$

K $\propto \varrho \omega \tau \alpha$ íเ $\alpha \quad 8$ w.n. 2; 12

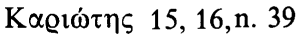

$\mathrm{K} \alpha \varrho \iota \omega \tau \tilde{\imath} v \alpha$ n. 39

K $\propto \varrho \iota \dot{\tau} \tau \gamma \lambda$ ov 15, n. $39 ; 18$

karkı, karğı 4

karkılık 4

$\mathrm{K} \dot{\alpha} \varrho \lambda \alpha \dot{\eta}, 18$, n. 48

$\mathrm{K} \alpha \dot{\varrho} \lambda \alpha \varsigma 18$

Karlı (and $K \alpha \varrho \lambda i) ~ 25$

Karlıköy 25

Karliova 21, 25, w.n. 71; 28

karlı ovası $\left({ }^{*} \mathrm{~K} \alpha \varrho \lambda \iota{ }^{\circ} \beta \alpha \sigma \iota\right) 21,28$

Karlıpınar 25

Karlitepe 25

Karlóva 16, 17, Kárlova n. 45

Karlóvas 13, 17

${ }^{*} \mathrm{~K} \alpha \varrho \lambda \mathrm{o} \beta \alpha \sigma \eta \eta \eta ், 17,18$

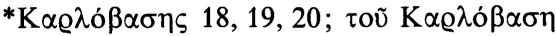
$18 ; \mathrm{K} \alpha \varrho \lambda \circ \beta \alpha \dot{\alpha} \sigma \eta \varsigma 19$

$\mathrm{K} \alpha \varrho \lambda \circ \beta \dot{\alpha} \sigma \alpha \tau \dot{\alpha} 14$

$\mathrm{K} \alpha \varrho \lambda \dot{\beta} \beta \alpha \sigma o v$ 14, n. 33

$\mathrm{K} \propto \varrho \lambda \circ \beta \alpha \dot{\alpha} \sigma o v$ (gen.) 14, n. 30, 31

$\mathrm{K} \alpha \varrho \lambda \hat{o} \beta \alpha \sigma \mathrm{l}$, second city in Samos $11 ; \mathrm{K} \alpha \varrho-$

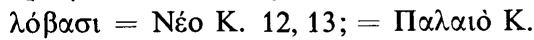
12, 13; K $\alpha \varrho \lambda o ́ \beta \alpha \sigma \mathrm{\imath}=\mathrm{K} \varrho \eta \tau \leftarrow \alpha \dot{\alpha} 19,20$,

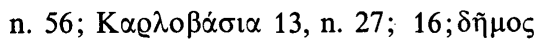




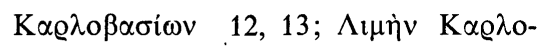
$\beta \alpha \sigma i \omega v 13$

$\mathrm{K} \alpha \varrho \lambda \circ \beta \alpha \dot{\alpha} \sigma \mathrm{los}$ (patrial) 14

$\left.\mathrm{K} \alpha \varrho \lambda \mathrm{o} \beta \alpha \sigma i \tau\rceil \varsigma(\&-\sigma i \omega \dot{\tau})_{\varsigma}\right) 14$

$\mathrm{K} \alpha \varrho \lambda \mathrm{o} \beta \alpha \sigma \mathrm{t} \omega \tau \eta$ (inhabitant of $\mathrm{K} \alpha \varrho \lambda$ ó $\beta \alpha \sigma \mathrm{t}$ in Kilkis area) 22, n. 63

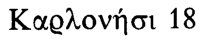

$\mathrm{K} \alpha \varrho \lambda$ os 18

Karlovasi in Samos 6-21; historical background $7-11$; description 11-12; name forms 12-14; review of etymological attempts 14-21.

Karlovasi in Macedonia 21-23; historical background and description 21-22; the story of the names 22 ; attempts at explanation 22-23

Karlóvasi; - in Samos, description n. 18; harbor of K. n. 18

Karlóvasi $=$ Neo Karlovasi $12 ;=$ Paleo K. 12 .

Karlovasí, K $\alpha \varrho \lambda \circ \beta \alpha \sigma i$ (so accented) (in area of Kilkis) 24, 30

Karlovo 15, 16

Karlu 25

Karluvasít's (K $\alpha \varrho \lambda \circ \beta \alpha \sigma i \tau \eta \varsigma) 14$

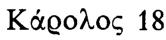

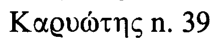

K $\alpha \sigma \tau \varrho i ́ 12$

$\mathrm{K} \alpha \tau^{\prime} \mathrm{B} \alpha \theta \dot{0} 9$

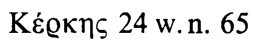

Kilic Ali 7, 8

Kilıc-köy 8

Kilkis area 21

Kirklıkova n. 93

kırlık 29, 30

Kirlıkova 29

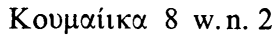

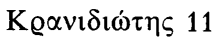

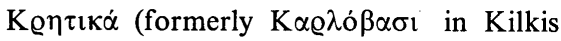
area) 22, n. 63

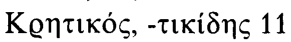

(Mt) Kruša n. 60

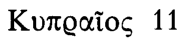

Kuşadası 26 w.n. 76

$\mathrm{K} \omega \tau \dot{\alpha} \kappa \eta \varsigma 11$

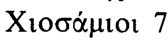

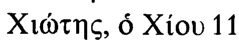

Chora, Xஸ́@ $\alpha 11,12$

$\Lambda \dot{\varepsilon} \kappa \alpha 9$ and n. 6

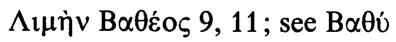

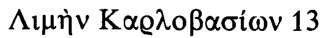

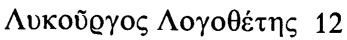

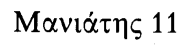

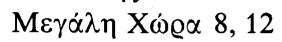

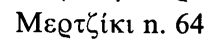

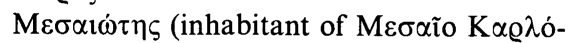
$\beta \alpha \sigma \imath) 14$

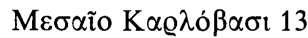

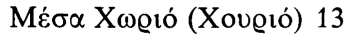

Meseo Karlovasi 12

methodology in onomastics 1,28

Mioíns 11

Mola Ibrahim n. 64

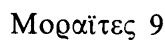

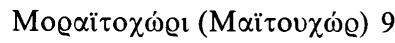

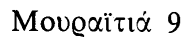

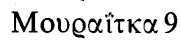

Mov@té $\zeta 21$, n. $60 ; 30$

$\mathrm{M} \pi \alpha \lambda \alpha \nu \tau \dot{\alpha} \beta \alpha \zeta 16$, and n. 75

(Mt.) Mycale n. 64

Múdoı 8

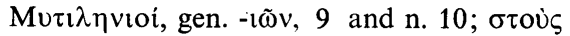

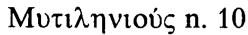

name: history of $a-1$

naming: procedure of -21

NÉo K $\alpha \varrho \lambda o ́ \beta \alpha \sigma \iota 13 ; \dot{x} \pi$ ó $\tau$ ò - - (patrial) 14

Neoк $\propto \varrho \lambda_{\circ} \beta \alpha \dot{\alpha} \sigma \mathrm{tov}$ n. 28

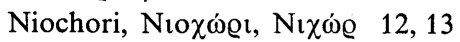

onomastic sciences 14

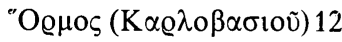

ova, ovas $24,25,28$; compds. in -ova 25 , -ovasi 25,28

ova-compounds 25

ovacık "little plain," Ovacık 25

$\Pi \alpha \lambda \alpha \imath$ Ko K$\alpha \varrho \lambda o ́ \beta \alpha \sigma \imath$ 11-12; Paleo Karlovasi 12 ; Palio-Karlovasi 30

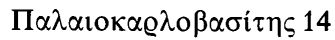

$\Pi \alpha \lambda$ เóк $\alpha \mu \pi$ os 27

Pambuk-ovası 27

$\Pi \alpha \dot{v}{ }^{\prime} \mathrm{K} \alpha \varrho \lambda \dot{\beta} \beta \alpha \sigma \mathrm{l} 13$

$\Pi \alpha \dot{\alpha}$ ' Xov@ı́ $=\Pi \alpha \lambda \alpha$ เò $\mathrm{K} \alpha \varrho \lambda$ ó $\beta \alpha \sigma ı 13$

$\Pi \alpha \xi$ ıvós 11

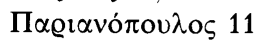

Pasaovası 26

Pasın-ovası 27

patrial suffix 14

place-name study 1

$-\pi$ oú $\lambda \alpha$ suff. of islets n. 5

$\Psi \alpha \dot{\imath \imath} 11$

Pulamash 21

Qarli 15

qarli-ova 15

reed, reedbed 29,30

renaming of place-names 1 


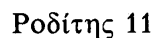

sambúla $(\Sigma \alpha \mu$ o $\pi$ ov́ $\lambda \alpha)$ n. 5

$\Sigma \dot{\alpha} \mu \iota \iota_{\zeta}, \Sigma \alpha \mu \iota \dot{\omega} \tau \varsigma \mathrm{s}$

$\Sigma \alpha \mu$ o

$\Sigma \dot{\alpha} \mu \circ \varsigma$ and $\Sigma \dot{\alpha} \mu \mathrm{o}(\mathfrak{\eta}) 8$

Samos Strait n. 64

Samsún 8;- Dağ n. 64

- $s l$ compounded Turk. nouns \& names 25,28

$\Sigma \varepsilon i ̈ \tau \dot{\alpha} v ı$ n. 64

Sisam (\& Susam) adası 8

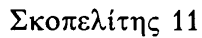

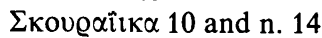

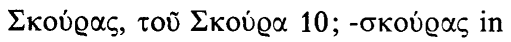

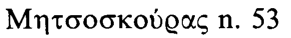

Skouras Brothers n. 15

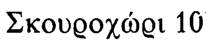

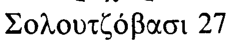

Söke (Sokya) 26, n. 76

$\Sigma \pi \imath \tau \alpha \pi \circ \theta \tilde{\eta} \kappa \varepsilon \varsigma$ n. 39a

$\Sigma \tau \alpha \theta \mu$ ò $\zeta$ Mov@ĩ̃v 21, 22

$\Sigma \tau \varepsilon v o ̀ ~ \tau \tilde{\jmath} \varsigma \Sigma \dot{\alpha} \mu o v$ n. 64

Sulucaova 28

Susam $8 ;-(\&$ Sisam) adası 8,24, n. 64

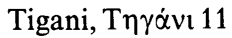

toponyms derived from family names 17

Turkish place-names in Samos n. 64

Urla (Turk.) 10

University of North Dakota

\section{NECROLOGY}

The Secretary-Treasurer regretfully announces the deaths of the following members:

Bertram Hughes

Symington Landreth

Maurice A. Mook

S. G. Morley

Mary Ann Williams 